Prepared in cooperation with the U.S. Environmental Protection Agency National Exposure Research Laboratory

\title{
Data Visualization, Time-Series Analysis, and Mass-Balance Modeling of Hydrologic and Water-Quality Data for the McTier Creek Watershed, South Carolina, 2007-2009
}

\section{National Water-Quality Assessment Program}

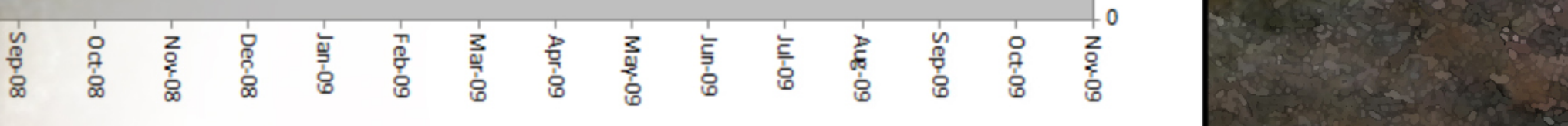

Open-File Report 2011-1209 
Cover art. Photographs of McTier Creek upstream from the streamgage near Monetta at the Secondary Road 25 crossing, Aiken County, South Carolina, August 17, 2007 (photographs by Toby D. Feaster, USGS). Screen capture of a TOPMODEL worksheet from the report. 


\section{Data Visualization, Time-Series Analysis, and Mass-Balance Modeling of Hydrologic and Water-Quality Data for the McTier Creek Watershed, South Carolina, 2007-2009}

By Stephen T. Benedict, Paul A. Conrads, Toby D. Feaster, Celeste A. Journey, Heather E. Golden, Christopher D. Knightes, Gary M. Davis, and Paul M. Bradley

National Water-Quality Assessment Program

Open-File Report 2011-1209 


\title{
U.S. Department of the Interior \\ KEN SALAZAR, Secretary \\ U.S. Geological Survey \\ Marcia K. McNutt, Director
}

\section{U.S. Geological Survey, Reston, Virginia: 2012}

\author{
For more information on the USGS — the Federal source for science about the Earth, its natural and living resources, \\ natural hazards, and the environment, visit http://www.usgs.gov or call 1-888-ASK-USGS \\ For an overview of USGS information products, including maps, imagery, and publications, \\ visit http://www.usgs.gov/pubprod \\ To order this and other USGS information products, visit http://store.usgs.gov
}

Any use of trade, product, or firm names is for descriptive purposes only and does not imply endorsement by the U.S. Government.

Although this report is in the public domain, permission must be secured from the individual copyright owners to reproduce any copyrighted materials contained within this report.

Suggested citation:

Benedict, S.T., Conrads, P.A., Feaster, T.D., Journey, C.A., Golden, H.E., Knightes, C.D., Davis, G.M., and Bradley, P.M., 2012, Data visualization, time-series analysis, and mass-balance modeling of hydrologic and water-quality data for the McTier Creek watershed, South Carolina, 2007-2009: U.S. Geological Survey Open-File Report 2011-1209, 21 p. 


\section{Contents}

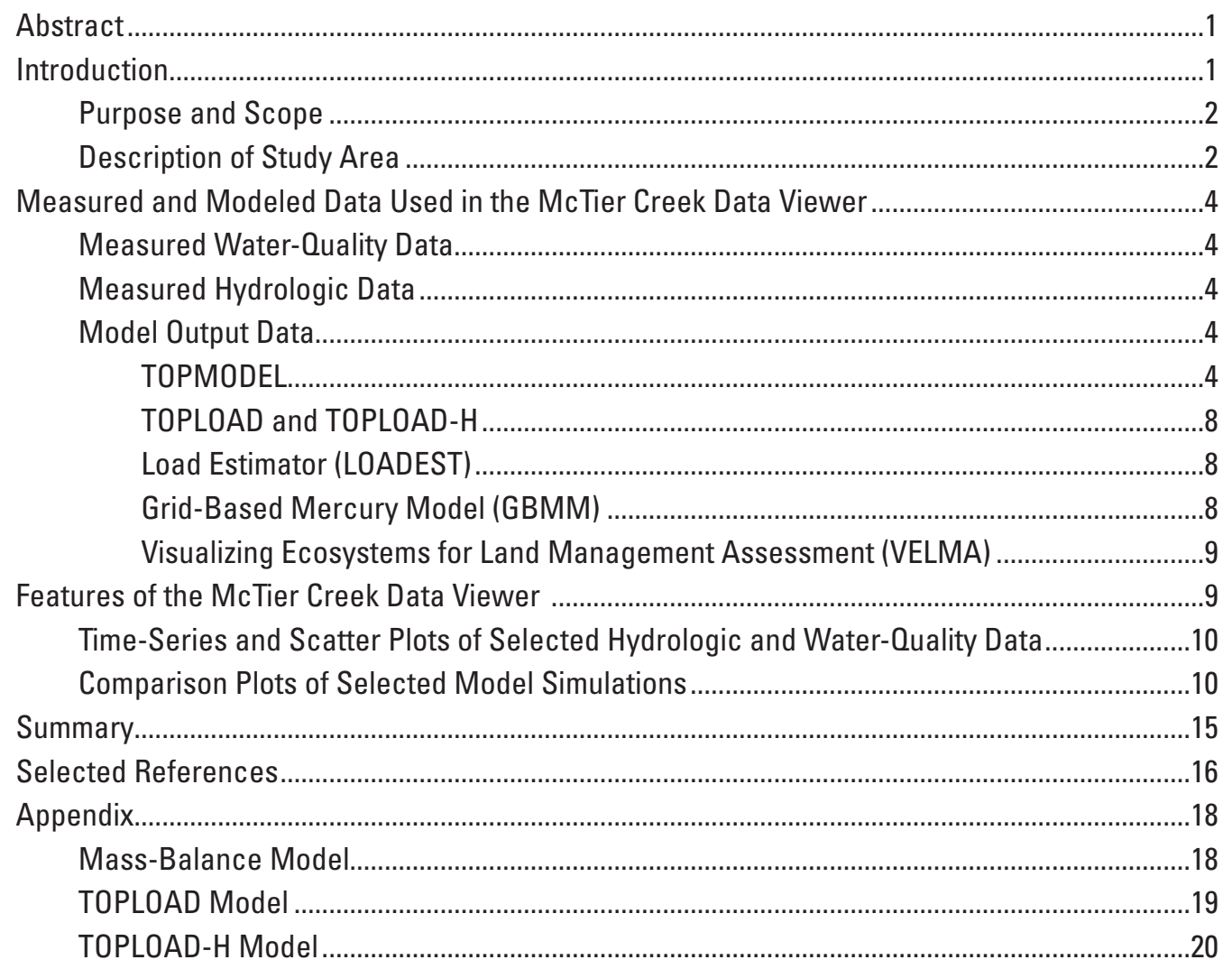

\section{Figures}

1. Map showing location of the McTier Creek watershed study area in Aiken

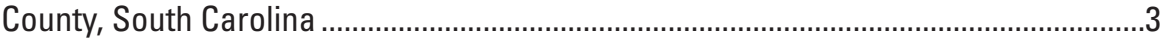

2. Diagram defining selected water-source variables from TOPMODEL...............................6

3. Screen capture from the McTier Creek Data Viewer showing "Title Sheet" worksheet .......................................................................................................12

4. Screen capture from the TOPMODEL worksheet showing dropdown menu of selected constituent to be shown with the measured flow data. ............................12

5. Screen capture from the TOPMODEL worksheet showing selected constituent concentration with the TOPMODEL simulated flow components.................................13

6. Screen capture from the scatter plot worksheet showing scatter plots of the selected constituent and various measured flow and simulated flow components.

7. Screen capture from the model comparison worksheet showing the measured and simulated flows from TOPMODEL, GBMM, and VELMA along with the selected constituent by season.

8. Screen capture from the model comparison worksheet showing the measured and simulated loads from TOPLOAD-H, LOADEST, GBMM, and VELMA...................14

A1. Screen capture from the TOPLOAD worksheet showing input table for manually assigning concentrations to the TOPMODEL flow components..................19

A2. Schematic showing the partitioning of the ground-water flow component .................20 


\section{Tables}

1. Measured in-stream hydrologic and water-quality data included in the McTier Creek Data Viewer collected from the New Holland streamflow-gaging station, June 2007 to August 2009.

2. Simulated hydrologic time-series data included in the McTier Creek Data Viewer for the New Holland streamflow-gaging station.

3. Simulated time-series water-quality loads included in the McTier Creek Data Viewer for the New Holland streamflow-gaging station...

4. Description of selected worksheets and applications included in the McTier Creek Data Viewer. 


\section{Conversion Factors}

Inch/Pound to SI

\begin{tabular}{lcl}
\hline Multiply & By & To obtain \\
\hline mile $(\mathrm{mi})$ & 1.609 & kilometer $(\mathrm{km})$ \\
square mile $\left(\mathrm{mi}^{2}\right)$ & 2.590 & square kilometer $\left(\mathrm{km}^{2}\right)$ \\
\hline
\end{tabular}

Horizontal coordinate information is referenced to North American Datum of 1983 (NAD 83).

Vertical coordinate information is referenced to North American Datum of 1988 (NAVD 88) or National Geodetic Vertical Datum of 1929 (NGVD 29). 


\title{
Acronyms and Variables Used in this Report
}

\author{
DEM Digital elevation map \\ GBMM Grid-Based Mercury Model \\ GIS Geographic information system \\ LOADEST LOAD ESTimator model \\ NAWQA National Water-Quality Assessment Program \\ NRCS-CN National Resource Conservation Service curve number \\ TOPMODEL TOPography-based hydrological MODEL \\ TOPLOAD Water-quality load model developed from TOPMODEL \\ TOPLOAD-H Water-quality load model developed from TOPMODEL with Hornberger's ground-water partitioning algorithm \\ USGS U.S. Geological Survey \\ VELMA Visualizing Ecosystems for Land Management Assessment model \\ ppt Precipitation \\ $q b \quad$ Subsurface flow \\ qimp Impervious flow \\ qinf Infiltration-excess overland flow \\ qof Overland saturation flow \\ qpred Total in-stream flow \\ qret Return flow \\ qsrip $\quad$ Flow from open-water bodies (lakes, ponds, precipitation directly into the channel)
}




\title{
Data Visualization, Time-Series Analysis, and Mass-Balance Modeling of Hydrologic and Water-Quality Data for the McTier Creek Watershed, South Carolina, 2007-2009
}

\author{
By Stephen T. Benedict, ${ }^{1}$ Paul A. Conrads, ${ }^{1}$ Toby D. Feaster ${ }^{1}$ Celeste A. Journey, ${ }^{1}$ Heather E. Golden, ${ }^{2}$ \\ Christopher D. Knightes, ${ }^{3}$ Gary M. Davis, ${ }^{3}$ and Paul M. Bradley ${ }^{1}$
}

\section{Abstract}

The McTier Creek watershed is located in the headwaters of the Edisto River Basin, which is in the Coastal Plain region of South Carolina. The Edisto ecosystem has some of the highest recorded fish-tissue mercury concentrations in the United States. In an effort to advance the understanding of the fate and transport of mercury in stream ecosystems, the U.S. Geological Survey, as part of its National Water-Quality Assessment Program, initiated a field investigation of mercury in the McTier Creek watershed in 2006. The initial efforts of the investigation included the collection of extensive hydrologic and water-quality field data, along with the development of several hydrologic and water-quality models. This series of measured and modeled data forms the primary source of information for this investigation to assess the fate and transport of mercury within the McTier Creek watershed.

The visualization of data is an important tool for understanding the trends and influencing variables of an ecosystem. One of the initial efforts for evaluating the hydrology and water quality in the McTier Creek watershed was the development of a digital spreadsheet for systematically visualizing and interrogating selected hydrologic, water-quality, and model data. This report briefly describes the development and application of the McTier Creek Data Viewer. The extensive database incorporated into the data viewer also provides a means for analysis and the development of analytical tools that may provide insights into the water quality within the McTier Creek watershed. One such application was the development of a simple water-quality load model that utilized a massbalance equation in conjunction with the topography-based hydrological model (TOPMODEL) developed to simulate flow in the McTier Creek watershed. Several variations of this simple load model were developed and are presented in the report.

\footnotetext{
${ }^{1}$ U.S. Geological Survey.

${ }^{2}$ U.S. Environmental Protection Agency, Office of Research and Development, Ecological Exposure Research Division, Cincinnati, Ohio.

${ }^{3}$ U.S. Environmental Protection Agency, Office of Research and Development, Ecosystems Research Division, Athens, Georgia.
}

\section{Introduction}

The bioaccumulation of mercury in the food chain of stream ecosystems is a public health concern in many parts of the United States (Mergler and others, 2007; Swain and others, 2007) and is one of the leading causes for impairment of the Nation's water bodies (U.S. Environmental Protection Agency, 2008). Inorganic mercury is typically delivered to stream ecosystems through atmospheric deposition (Grigal, 2002). Under reducing conditions, inorganic mercury can be converted to methylmercury, which is highly toxic and biomagnifies at the top of the food chain (Wiener and others, 2003). An understanding of the fate and transport of methylmercury in stream ecosystems is critical. The U.S. Geological Survey (USGS) through its National Water-Quality Assessment (NAWQA) Program has been conducting field investigations of mercury with the goal of advancing the knowledge and ultimately developing tools to assist water officials in managing and mitigating the adverse effects of mercury in stream ecosystems.

The McTier Creek watershed is located in the headwaters of the Edisto River Basin in Aiken County, South Carolina. The Edisto River has some of the highest recorded fish-tissue mercury concentrations in the United States (Scudder and others, 2009). To better understand why these high concentrations exist, the USGS collected hydrologic and water-quality data in the McTier Creek watershed including continuous streamflow at several streamflow-gaging stations and numerous discrete samples for 48 water-quality constituents over a 30-month period (Bradley and others, 2010; 2011).

In addition to the field data, several hydrologic and water-quality models were developed for the McTier Creek watershed. These models include the following:

- GBMM-Grid-Based Mercury Model (Dai and others, 2005; Feaster and others, 2010);

- VELMA - Visualizing Ecosystems for Land Management Assessment (A. Abdelnour, Georgia Institute of Technology, written commun., 2011; G. Davis and C. Knightes, U.S. Environmental Protection Agency, written commun., 2011; H. Golden, U.S. Environmental Protection Agency, written commun., 2011); 
- LOADEST-LOAD ESTimator model (Runkel and others, 2004; C. Journey, U.S. Geological Survey, written commun., 2010); and

- TOPMODEL-TOPography-based hydrological MODEL (Wolock, 1993; Feaster and others, 2010).

These models provide tools to evaluate the hydrology and the fate and transport of mercury and other water-quality constituents within the McTier Creek watershed. The hydrologic and water-quality field data, as well as the modeled flow data, for the watershed collectively comprise an extensive resource for understanding the chemical, biological, and hydrologic characteristics that influence the methylation, transport, and bioaccumulation of mercury in stream ecosystems.

As with any research endeavor, the visualization of data can be an important tool for evaluation of the hydrologic and water-quality trends and influencing variables of an ecosystem. Therefore, the McTier Creek Data Viewer was developed to integrate the various measured hydrologic and water-quality data and simulated model data. The McTier Creek Data Viewer provides a spreadsheet application so researchers can quickly visualize and interrogate the data and model output for the McTier Creek watershed and also provides a foundation for the development of analysis tools that may give insight into the quality of water in the McTier Creek watershed. One such application was the development of a simple waterquality load model that utilized a mass-balance equation in conjunction with the hydrologic simulations from the McTier Creek TOPMODEL (Feaster and others, 2010). Several variations of this load model were developed. One variation, called TOPLOAD, used the unadjusted TOPMODEL hydrologic data. A second variation, called TOPLOAD-H, modified the subsurface hydrologic components with a ground-water partitioning algorithm presented in Hornberger and others (1994), hence the "H" in TOPLOAD-H. A detailed comparison of TOPLOAD and TOPLOAD-H with the other waterquality models developed in the McTier Creek investigation can be found in Golden and others (2012).

\section{Purpose and Scope}

The purposes of this report are to briefly describe the (1) measured and modeled hydrologic and water-quality data used in the development of the McTier Creek Data Viewer; (2) development and application of the data viewer used to visualize trends in measured and modeled hydrologic and water-quality data associated with the McTier Creek watershed investigation of mercury; and (3) development of the TOPLOAD and TOPLOAD-H water-quality load models for the McTier Creek watershed based on a mass-balance equation in conjunction with the hydrologic simulations from the TOPMODEL. Plots of load computations for TOPLOAD, TOPLOAD-H, LOADEST, GBMM, and VELMA were developed in the data viewer, and selected results are presented in this report.
An important role of the USGS mission is to provide scientific information for the effective management of the Nation's water resources. The techniques presented in this report demonstrate how valuable information can be extracted from disparate databases of continuous time-series data, non-periodic discrete data, and model simulation output into a user-friendly spreadsheet application to meet the needs of researchers. The techniques are readily applicable to other systems for evaluation of historical data and simulation models.

\section{Description of Study Area}

McTier Creek is a small headwaters stream located in the Edisto River Basin and is a tributary to the South Fork Edisto River (fig. 1). The entire McTier Creek watershed encompasses about $38 \mathrm{mi}^{2}$ in Aiken County, South Carolina, and is designated by the 12-digit hydrologic unit code 030502040102 (Eidson and others, 2005). The study area is primarily rural, with land-cover categories that include 50 percent forest, 20 percent grassland/herbaceous, 16 percent agriculture, 8 percent wetland, 5 percent developed, and about 1 percent open water (National Land Coverage Data 2001; Homer and others, 2004).

The McTier Creek watershed lies within the inland part of the Coastal Plain Physiographic Province, known as the Sand Hills (fig. 1), in South Carolina (Vigil and others, 2000; Griffith and others, 2002). Some studies integrate the Sand Hills within a broader area referred to as the inner or upper Coastal Plain (Bloxham, 1976; Marshall, 1993; Bennett and Patton, 2008). The McTier Creek watershed begins near the Fall Line (fig. 1), which marks the transition from the Piedmont to the upper Coastal Plain (Cooke, 1936). The McTier Creek watershed displays transitional characteristics in which the upper part of the watershed has Piedmont characteristics with steep gradients and rock outcrops, transitioning to a lower gradient stream with riparian floodplains characteristic of the Coastal Plain.

The surficial geology of the McTier Creek watershed is dominated by an outcrop of the highly permeable sediments of the Tertiary sand aquifer that covers much of the southwestern part of the upper Coastal Plain in South Carolina. The Tertiary sand aquifer within this region is noted for high ground-water recharge rates, steep ground-water potentiometric gradients, and substantial ground-water contributions to total streamflow (Aucott and Speiran, 1985). The prominent contribution of ground water to the hydrology of the McTier Creek watershed is considered an important factor in the fate and transport of mercury within the system (Bradley and others, 2010). There are two USGS streamflow-gaging stations located in the McTier Creek watershed: station 02172300, McTier Creek near Monetta, South Carolina, and station 02172305, McTier Creek near New Holland, South Carolina (fig. 1). Hereafter, these stations will be referred to as Monetta and New Holland, respectively. Data from these streamflow-gaging stations provide a valuable resource for understanding the hydrology of the McTier Creek watershed. 


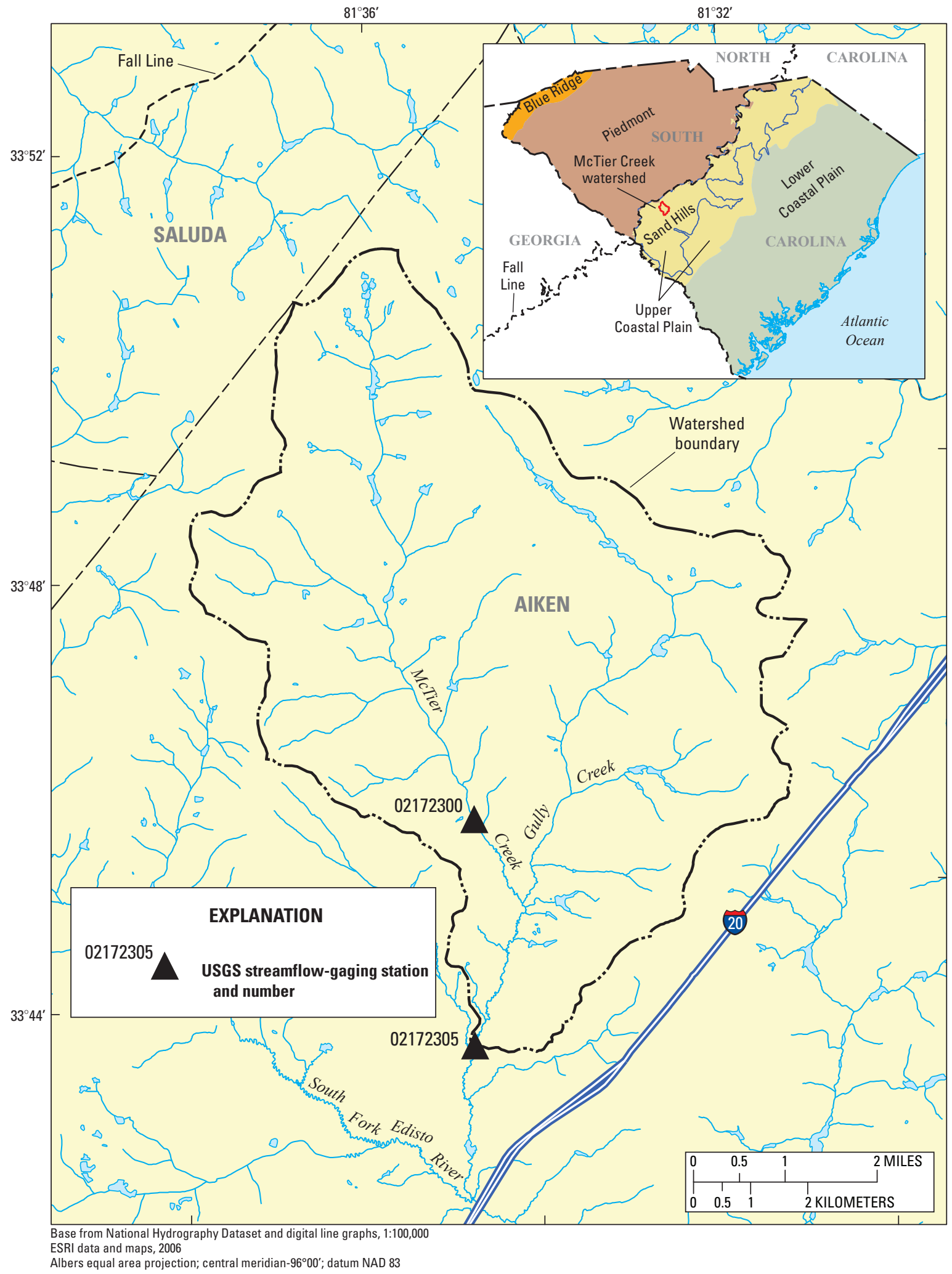

Figure 1. Location of the McTier Creek watershed study area in Aiken County, South Carolina. [USGS, U.S. Geological Survey] 


\section{Measured and Modeled Data Used in the McTier Creek Data Viewer}

An extensive set of measured and modeled data was collected to investigate the fate and transport of mercury and other water-quality constituents within the McTier Creek watershed. Selected data were compiled into the McTier Creek Data Viewer including water-quality and hydrologic field measurements and model data from TOPMODEL, TOPLOAD, TOPLOAD-H, LOADEST, GBMM, and VELMA. A brief description of the selected data is provided in this section. The data compiled in the McTier Creek Data Viewer are a subset of the larger database for the McTier Creek watershed, which can be accessed at http://pubs.usgs.gov/sir/2012/5173/(Journey and others, 2012).

\section{Measured Water-Quality Data}

Sampling of water quality was conducted at the McTier Creek watershed from June 2007 to August 2009. Measurements were made for in-stream bimonthly samples, in-stream time-series samples over selected hydrographs, and watershed synoptic samples to define the spatial variation of water quality within the surface water, ground water, and riparian wetlands. The in-stream bimonthly and time-series samplings included 45 samples collected primarily at the USGS New Holland streamflow-gaging station (fig. 1). The synoptic samplings included 42 samples collected at selected locations throughout the watershed (Bradley and others, 2011). All samples were collected and analyzed according to USGS protocols (Brigham and others, 2009). Collected water-quality data included about 450 discrete measurements of 48 constituents. The in-stream water-quality data were the primary data used in the McTier Creek Data Viewer to assess the relation between hydrologic factors and selected water-quality measurements.

\section{Measured Hydrologic Data}

Streamflow data were collected from the Monetta and New Holland streamflow-gaging stations (fig. 1). Monetta had a period of record from October 1995 to September 1997 and from February 2001 to September 2009. New Holland was established specifically for the McTier Creek watershed study with a period of record from June 2007 to September 2009. Streamflow data at both gaging stations were continuously collected at 15-minute intervals using standard techniques (Rantz and others, 1982). Streamflow data collected from June 2007 to August 2009 are the primary hydrologic data in the data viewer, particularly from New Holland - the primary in-stream water-quality sampling station. The measured waterquality and hydrologic data in the McTier Creek Data Viewer are listed in table 1.

\section{Model Output Data}

Computerized process-based models can be useful tools to gain insight into complex ecosystem processes. The McTier Creek watershed investigation developed several hydrologic and (or) water-quality models, including TOPMODEL, TOPLOAD, TOPLOAD-H, LOADEST, GBMM, and VELMA. There are specific uses and limitations associated with each model; together the models are useful for testing various hypotheses regarding the McTier Creek watershed. The worksheet "ReleaseNotes" in the McTier Creek Data Viewer provides references on the model configuration being used in the data viewer. The models, simulation period, and the hydrologic and water-quality model outputs are listed in tables 2 and 3, respectively. Brief descriptions of each model are described herein.

\section{TOPMODEL}

TOPMODEL (a TOPography-based hydrological MODEL) is a physically based watershed model that simulates streamflow based on the variable source-area concept of streamflow generation. It is a semidistributed model that groups hydrologically similar portions of a watershed based on a topographic index. In the variable source-area concept, saturation land-surface areas are sources of streamflow during precipitation events in several ways. Saturation overland flow (also called Dunne overland flow) is generated if the subsurface hydraulic characteristics are not transmissive and if slopes are gentle and convergent (Dunne and Black, 1970; Wolock, 1993). Saturation overland flow can arise from direct precipitation on the saturated land-surface areas or from return flow of subsurface water to the surface in the saturated areas. Subsurface stormwater flow is generated if the nearsurface soil zone is very transmissive (large saturated hydraulic conductivity) and if gravitational gradients (slopes) are steep. Whipkey (1965) defined subsurface stormwater flow as underground stormwater flow that reaches the stream channel without entering the ground-water storage zone.

TOPMODEL is a process-based watershed hydrology model that systematically accounts for water as it enters the watershed as precipitation (ppt) until it leaves the watershed through evapotranspiration (pet), by direct withdrawal, or as streamflow (qpred) (fig. 2). In the water balance, precipitation on a given day is used first to satisfy the potential evapotranspiration for the day. The remainder moves overland to a stream if the precipitation falls on an impervious surface that is connected to a stream (qimp), soil that is already saturated (qof), or soil through which the water cannot infiltrate rapidly enough (qinf). Precipitation that falls on a surface-water body is added to the streamflow (qsrip). The remaining water infiltrates into the upper soil zone. Any water stored in the saturated subsurface zone is assumed to move downslope toward the stream channel and enters the stream as return flow (qret) in saturated areas and (or) subsurface flow $(q b)$ at the stream 
Table 1. Measured in-stream hydrologic and water-quality data included in the McTier Creek Data Viewer collected from the New Holland streamflow-gaging station, June 2007 to August 2009.

\begin{tabular}{|c|c|}
\hline Constituent & Units \\
\hline \multicolumn{2}{|c|}{ Time-Series Hydrologic Data } \\
\hline Streamflow & cubic feet per second \\
\hline \multicolumn{2}{|c|}{ Discrete In-Stream Water-Quality Data } \\
\hline Air temperature & Degrees Celsius \\
\hline Water temperature & Degrees Celsius \\
\hline Field $\mathrm{pH}$ & Standard units \\
\hline Field specific conductance & Microsiemens per centimeter \\
\hline Laboratory specific conductance & Microsiemens per centimeter \\
\hline Laboratory alkalinity & Milligrams per liter as calcium carbonate \\
\hline Dissolved ammonia & Milligrams per liter \\
\hline Dissolved calcium & Milligrams per liter \\
\hline Dissolved chloride & Milligrams per liter \\
\hline Dissolved iron & Micrograms per liter \\
\hline Dissolved magnesium & Milligrams per liter \\
\hline Dissolved nitrate plus nitrite & Milligrams per liter \\
\hline Dissolved nitrite & Milligrams per liter \\
\hline Dissolved organic carbon & Milligrams per liter \\
\hline Dissolved orthophosphate & Milligrams per liter \\
\hline Dissolved oxygen concentration & Milligrams per liter \\
\hline Dissolved potassium & Milligrams per liter \\
\hline Dissolved silica & Milligrams per liter \\
\hline Dissolved sodium & Milligrams per liter \\
\hline Dissolved sulfate & Milligrams per liter \\
\hline Total nitrogen & Milligrams per liter \\
\hline Total phosphorus & Milligrams per liter \\
\hline Suspended inorganic carbon & Milligrams per liter \\
\hline Suspended organic carbon & Milligrams per liter \\
\hline Suspended sediment & Milligrams per liter \\
\hline Suspended sediment finer than 63 microns & Percent \\
\hline Suspended total carbon & Milligrams per liter \\
\hline Suspended total nitrogen & Milligrams per liter \\
\hline Filtered methylmercury & Nanograms per liter \\
\hline Filtered total mercury & Nanograms per liter \\
\hline Particulate methylmercury & Nanograms per liter \\
\hline Particulate total mercury & Nanograms per liter \\
\hline Total mercury (filtered plus particulate total mercury) & Nanograms per liter \\
\hline Hydrophilic acid to specific ultraviolet absorbance ratio & Fraction \\
\hline Hydrophilic acids & Percent \\
\hline Hydrophobic organic acid to specific ultraviolet absorbance ratio & Fraction \\
\hline Hydrophobic organic acids & Percent \\
\hline
\end{tabular}


Table 1. Measured in-stream hydrologic and water-quality data included in the McTier Creek Data Viewer collected from the New Holland streamflow-gaging station, June 2007 to August 2009._Continued

\begin{tabular}{ll}
\hline \multicolumn{1}{c}{ Constituent } & \multicolumn{1}{c}{ Units } \\
\hline \multicolumn{1}{c}{ Discrete In-Stream Water-Quality } & Data-Continued \\
\hline Transphillic acid to specific ultraviolet absorbance ratio & Fraction \\
Transphillic acids & Percent \\
Ash-free phytoplankton biomass & Milligrams per liter \\
Chlorophyll $a$ & Micrograms per liter \\
Pheophytin $a$ & Micrograms per liter \\
Phytoplankton biomass as ash weight & Milligrams per liter \\
Phytoplankton biomass as dry weight & Milligrams per liter \\
Computed ultraviolet absorbance at 254 nanometers & Per centimeter (corrected for iron concentration) \\
Specific ultraviolet absorbance & Milligrams per liter DOC per meter \\
Ultraviolet absorbance at 254 nanometers & Per centimeter \\
Ultraviolet absorbance at 365 nanometers & Per centimeter \\
\hline
\end{tabular}

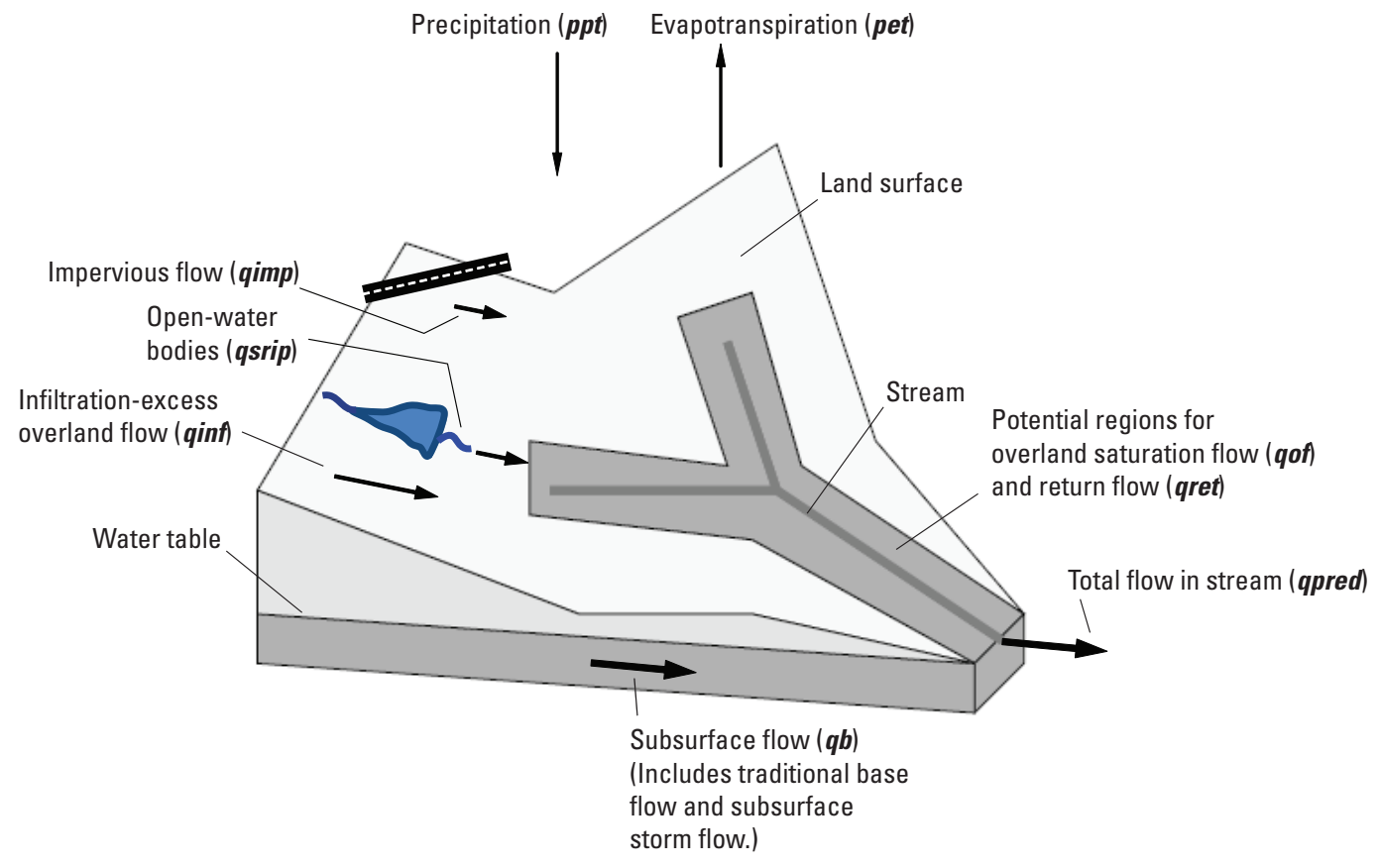

Figure 2. Definition of selected water-source variables from TOPMODEL (modified from Wolock, 1993). 
Table 2. Simulated hydrologic time-series data included in the McTier Creek Data Viewer for the New Holland streamflowgaging station.

[TOPMODEL, Topography-Based Hydrological Model; GBMM, Grid-Based Mercury Model; VELMA, Visualizing Ecosystems for Land Management Assessment Model]

\begin{tabular}{lll}
\hline \multicolumn{1}{c}{ Variable } & \multicolumn{1}{c}{ Variable definition } & \multicolumn{1}{c}{ Units } \\
\hline \multicolumn{3}{c}{ Selected TOPMODEL Output } \\
\multicolumn{3}{c}{ (Wolock, 1993; Feaster and others, 2010) } \\
acsat & $\begin{array}{c}\text { Percent of the area predicted to } \\
\text { be saturated }\end{array}$ & Percent \\
& Average (over all wetness index & Millimeters per day \\
aversz & bins) storage in the root zone & \\
& Average (over all wetness index & \\
avesuz & bins) storage in the unsatu- & Millimeters per day \\
& rated zone & \\
pet & Potential evapotranspiration & Millimeters per day \\
pettot & Actual evapotranspiration & Millimeters per day \\
ppt & Precipitation & Millimeters per day \\
qb & Base flow & Millimeters per day \\
qimp & Flow from impervious areas & Millimeters per day \\
qinf & Infiltration excess & Millimeters per day \\
qof & Overland flow & Millimeters per day \\
qpred & Total predicted flow at basin outlet & Millimeters per day \\
qret & Return flow & Millimeters per day \\
qrip & Flow from open-water bodies & Millimeters per day \\
quz & Flow in unsaturated zone & Millimeters per day \\
S & Average saturation deficit & Millimeters per day \\
\hline
\end{tabular}

Selected GBMM Output

(Dai and others, 2005; Feaster and others, 2010)

Simulation Period: June 13, 2007 through September 30, 2009

Evap Evapotranspiration for the day Centimeters per day

Gout Groundwater outflow, base flow Centimeters per day

Gwat Groundwater storage Centimeters per day

Perc Percolation to the shallow Centimeters per day ground water

Ptot Total precipitation (rain + snow- Centimeters per day melt) for the day

Roff Surface runoff for the day Centimeters per day

Swat Soil water storage Centimeters per day

Seep Seepage to the deep Centimeters per day ground water

Total flow Total predicted flow at basin outlet Centimeters per day

Selected VELMA Output

(A. Abdelnour, Georgia Institute of Technology, written commun., 2011;

G. Davis and C. Knightes, U.S. Environmental Protection Agency, written commun,, 2011)

Simulation Period: June 13, 2007 through September 30, 2009

Discharge Total predicted flow at basin outlet Cubic feet per second per day

Table 3. Simulated time-series water-quality loads included in the McTier Creek Data Viewer for the New Holland streamflowgaging station.

[TOPLOAD, Water-quality load model developed from TOPMODEL; TOPLOAD-H, Water-quality load model developed from TOPMODEL with Hornberger's (Hornberger and others, 1994) groundwater partitioning algorithm; GBMM, Grid-Based Mercury Model; VELMA, Visualizing Ecosystems for Land Management Assessment Model; LOADEST, LOAD ESTimator model]

\begin{tabular}{c}
\hline Constituent \\
TOPLOAD and TOPLOAD-H \\
(see appendix) \\
Simulation period: June 13, 2007 through September 30, 2009 \\
\hline
\end{tabular}

Dissolved calcium

Dissolved chloride

Dissolved sulfate

Filtered total mercury

Dissolved sodium

Dissolved organic carbon

Total mercury (filtered plus particulate total mercury)

\begin{tabular}{|c|c|}
\hline \multicolumn{2}{|c|}{$\begin{array}{l}\text { GBMM } \\
\text { (Dai and others, 2005; Feaster and others, 2010) } \\
\text { Simulation period: June 13, } 2007 \text { through September 30, } 2009\end{array}$} \\
\hline Total mercury & Milligrams per day \\
\hline Total suspended solids & Kilograms per day \\
\hline \multicolumn{2}{|c|}{$\begin{array}{c}\text { VELMA } \\
\text { (A. Abdelnour, Georgia Institute of Technology, } \\
\text { written commun., 2011 } \\
\text { G. Davis and C. Knightes, U.S. Environmental } \\
\text { Protection Agency, written commun, 2011) } \\
\text { Simulation period: June 13, } 2007 \text { through September 30, } 2009\end{array}$} \\
\hline Total mercury & Milligrams per day \\
\hline Dissolved organic carbon & Kilograms per day \\
\hline $\begin{array}{l}\text { Dissolved inorganic } \\
\text { nitrogen }\end{array}$ & Kilograms per day \\
\hline Dissolved organic nitrogen & Kilograms per day \\
\hline \multicolumn{2}{|c|}{$\begin{array}{c}\text { LOADEST } \\
\text { (Runkel and others, 2004) } \\
\text { Simulation period: October 1, } 2004 \text { through September 30, } 2009\end{array}$} \\
\hline Filtered methylmercury & Milligrams per day \\
\hline Filtered total mercury & Milligrams per day \\
\hline Particulate total mercury & Milligrams per day \\
\hline Particulate methylmercury & Milligrams per day \\
\hline $\begin{array}{l}\text { Total mercury (filtered } \\
\text { plus particulate total } \\
\text { mercury) }\end{array}$ & Milligrams per day \\
\hline Dissolved organic carbon & Kilograms per day \\
\hline Suspended sediment & Kilograms per day \\
\hline Particulate organic carbon & Kilograms per day \\
\hline Dissolved chloride & Kilograms per day \\
\hline Dissolved sulfate & Kilograms per day \\
\hline
\end{tabular}

Kilograms per day

Kilograms per day

Kilograms per day

Milligrams per day

Kilograms per day

Kilograms per day

Milligrams per day

\section{GBMM}

(ember 30, 2009 
banks. The portion of the subsurface water that drains into the stream depends on the volume in storage and the values of the TOPMODEL input parameters.

\section{TOPLOAD and TOPLOAD-H}

The version of TOPMODEL applied to the McTier Creek investigations (Feaster and others, 2010) does not include a mass-balance algorithm for evaluating water-quality loads. However, such an algorithm can be applied externally to the surface and subsurface flows simulated by the TOPMODEL leading to a load model that can assess the mass fluxes for a given water-quality constituent. The development of a water-quality load model by the application of a mass-balance algorithm to the TOPMODEL output is simple and allows flexibility for testing variations in the underlying algorithm. As previously mentioned, several variations of the load model were developed for this study. One variation, TOPLOAD, used the unadjusted TOPMODEL hydrologic flow components. A second variation, TOPLOAD-H, modified the subsurface hydrologic components of TOPMODEL using the groundwater partitioning algorithm presented in Hornberger and others (1994). The synoptic water-quality data in conjunction with the in-stream data were used to assign concentrations to various surface and subsurface flow components in the development of the TOPLOAD and TOPLOAD-H models. A brief description of the development of these simple load models is presented in the appendix. The TOPLOAD and TOPLOAD-H load models were applied to selected water-quality constituents (table 3) in the McTier Creek watershed, and the results were incorporated into the data viewer.

\section{Load Estimator (LOADEST)}

Loads for selected water-quality constituents (table 3) were computed using the S-LOADEST (Lorenz and others, 2011) plug-in for TIBCO Spotfire S+ 8.1® software (TIBCO Spotfire Co., Palo Alto, Calif.). S-LOADEST is derived from LOADEST, a FORTRAN program that has been used extensively for estimating constituent loads in streams and rivers (Runkel and others, 2004). S-LOADEST allows the user to estimate annual, monthly, and seasonal constituent loads using a regression (rating curve) approach (Cohn, 2005). The regression model computes daily loads based on relations between constituent load and explanatory variables that are functions of streamflow and time. The time component can be represented as increasing and decreasing trends over time and as seasonal changes.

Instantaneous constituent loads are computed by the following equation:

$$
L_{H g}=C_{H g} * Q_{i} * C_{l},
$$

where

$$
\begin{gathered}
L_{H g} \quad \begin{array}{r}
\text { is the mercury species (or other constituent } \\
\text { of interest) load at the time of sampling, } \\
\text { in milligrams per day, }
\end{array} \\
\begin{array}{c}
C_{H g} \quad \begin{array}{l}
\text { is the concentration of the mercury species } \\
\text { (or other constituent of interest), in }
\end{array} \\
\text { nanograms per liter; }
\end{array} \\
Q_{i} \quad \text { is the instantaneous streamflow at the time of } \\
\quad \text { sampling, in cubic feet per second; and } \\
C_{l} \quad \text { is a unit conversion factor (2.447). }
\end{gathered}
$$

Yields are computed as:

$$
Y_{H g}=\left(L_{H g} / D A\right) * C_{y},
$$

where

$Y_{H g} \quad$ is the mercury species (or other constituent of interest) yield, in micrograms per hectare per day;

$L_{H g} \quad$ is the mercury species (or other constituent of interest) load at the time of sampling in milligrams per day;

$D A \quad$ is the upstream watershed drainage area, in hectares; and

$C_{y} \quad$ is a unit conversion factor $(1,000)$.

The LOADEST program contains nine predefined regression models that can be used to estimate loads that account for the different possible combinations of explanatory variables of streamflow and time. The load equation (model 6) used in this study is as follows:

$L=\beta o+\beta_{1} \operatorname{Ln} Q+\beta_{2} \operatorname{Ln} Q^{2}+\beta_{3} \operatorname{sine}(2 \pi T)+\beta_{4} \operatorname{cosine}(2 \pi T)$

where

$L \quad$ is the natural logarithm (log) of the estimated load, in milligrams per day;

$\beta_{n} \quad$ are the estimated coefficients for each variable;

$Q \quad$ is the $\log$ of the daily mean streamflow, in cubic feet per second;

$\pi \quad$ is pi (3.14); and

$T$ is the centered time in decimal years.

For the constituent of interest, the formulated regression model was used to estimate loads over a selected time interval (estimation period), October 2004 to September 2009.

\section{Grid-Based Mercury Model (GBMM)}

The Grid-Based Mercury Model (GBMM) was designed to simulate the daily fluxes and mass balances of water, sediment, and mercury at watershed outlets using a spatially explicit, process-based, model structure. The model has three main modules that compute daily mass balances of hydrology, sediment, and mercury within each geographic information 
system (GIS) raster grid cell. Daily fluxes of water, sediment, and mercury from each grid cell are routed through the watershed tributary networks to assessment points along stream channels.

The GBMM performs a simple water balance and estimates a modified National Resource Conservation Service curve number (NRCS-CN) for each grid cell on a daily basis. The mass balance of mercury at the watershed outlet is simulated using the equation:

$$
\begin{aligned}
& \quad \frac{d C_{s}}{d t}=\frac{L}{V_{s}}-\left(K_{r}+K_{l}+K_{r o}+K_{e}\right) * C_{s}, \\
& L=L_{p} \quad \text { for pervious surfaces } \\
& L=L_{f}+L_{d} \quad \text { for forested areas } \\
& V_{s}=A_{c} * z_{d}
\end{aligned}
$$

where

$C_{s} \quad$ is the concentration of mercury in watershed soils, in micrograms per cubic meter;

$L \quad$ is the mercury deposition load, in micrograms per day;

$V_{s} \quad$ is the watershed soil volume, in cubic meters;

$K_{r}$ is the reduction rate constant, in per day, where reduced mercury is assumed to immediately volatilize and is considered a loss from the watershed;

$K_{l} \quad$ is the leaching loss constant, in per day;

$K_{r o} \quad$ is the runoff loss constant, in per day;

$K_{e} \quad$ is the erosion loss constant, in per day;

$L_{p} \quad$ is the mercury deposition load on pervious land, in micrograms per day;

$L_{f} \quad$ is the mercury deposition load on forest land, in micrograms per day;

$L_{d} \quad$ is the litter decomposition mercury load on forestland, in micrograms per day;

$A_{c} \quad$ is the grid area, in square meters; and

$z_{d} \quad$ is the watershed soil mixing depth, in meters.

The current version of GBMM is structured to partition total mercury between its solid and aqueous forms in the soil system. Therefore, by calibrating the partition coefficient in the model (i.e., the ratio of the equilibrium concentration in the soil particle to the concentration in soil water), GBMMsimulated total mercury dynamics are largely associated with particulate production and movement from soils to surface waters. GBMM has been applied and validated in multiple settings in the southeastern United States, including the Piedmont Physiographic Province (Golden and others, 2010) and Coastal Plain Physiographic Province (Dai and others, 2005; Feaster and others, 2010). (Note: The GBMM loads were converted to units shown in table 3 for comparison with other models.)

\section{Visualizing Ecosystems for Land Management Assessment (VELMA)}

The Visualizing Ecosystems for Land Management Assessment (VELMA) model is a spatially distributed ecohydrological model that simulates soil water infiltration and redistribution, evapotranspiration, surface and subsurface runoff, carbon and nitrogen cycling in plants and soils, and the transport of dissolved organic carbon, dissolved inorganic nitrogen, and dissolved organic nitrogen from the terrestrial landscape to streams (A. Abdelnour, Georgia Institute of Technology, written commun., 2011). Recently, dissolved organic carbon driven mercury components were added to the existing VELMA framework (G. Davis and C. Knightes, U.S. Environmental Protection Agency, written commun., 2011). The VELMA uses a distributed soil column framework to simulate the lateral and vertical movement of water, heat, and nutrients within the soil. The modeling domain of VELMA is a 3-dimensional matrix covering the topographical surface (x-y) and four soil layers (z). The soil column model consists of three coupled submodels:

Hydrological model - This model simulates vertical and lateral movement of water within the soil, and losses of water from the soil and vegetation to the atmosphere;

Soil temperature model - This model simulates daily ground soil layer temperatures from surface air temperature and snow depth; and

Biogeochemistry model-This model simulates carbon, nitrogen, and mercury dynamics.

The soil column model is then placed within a catchment framework to create a spatially distributed model applicable to watersheds and landscapes. Adjacent soil columns interact with each other through the downslope lateral transport of water. Surface and subsurface lateral flow are routed using a multiple flow direction method. A digital elevation map (DEM) is used to determine flow direction and compute the flow contribution area. Required input data include air temperature, precipitation, soil texture, soil depth, and DEM.

\section{Features of the McTier Creek}

\section{Data Viewer}

The abundant hydrologic and water-quality data associated with the McTier Creek watershed mercury investigation necessitates the integration of the datasets into a visualization tool for understanding the trends and influencing variables of the stream ecosystem. Therefore, one of the initial efforts for evaluating trends in the McTier Creek watershed was the development of a tool, or data viewer, for systematically visualizing combinations of selected hydrologic, water-quality, and model data. The McTier Creek Data Viewer was developed by organizing selected data into a Microsoft Excel ${ }^{\circledR}$ spreadsheet with applications that provide a means for developing various plots for visualizing trends. Worksheets and applications that 
comprise the McTier Creek Data Viewer are listed in table 4. A screen capture of the "Title Sheet" worksheet in the McTier Creek Data Viewer Microsoft Excel ${ }^{\circledR}$ application is shown in figure 3.

While a broad array of plots potentially could be developed with the data viewer, primary attention was given to developing graphs to display (1) time-series plots and scatter plots of selected hydrologic and water-quality data, (2) seasonal trends associated with selected water-quality constituents, and (3) comparison plots of selected model simulations. Brief descriptions of these data viewer functions are described in this section.

\section{Time-Series and Scatter Plots of Selected Hydrologic and Water-Quality Data}

Hydrology is an important determinant of ecosystem water quality (Bradley and others, 2010). The various hydrologic components (surface and subsurface flow) deliver waterquality constituents of varying concentrations to a stream and determine the in-stream water quality and ultimately the water-quality loads of the ecosystem. In order to understand the relation between in-stream water quality and the surface and subsurface hydrology, time-series plots and scatter plots of selected in-stream water-quality constituents in relation to measured and modeled flow components were developed in the McTier Creek Data Viewer. The in-stream water-quality measurements concurrent with streamflow measurements occur at the New Holland streamflow-gaging station from June 2007 to August 2009. Therefore, the plots in the data viewer were limited to modeled and measured data associated with this gaging station and time period.

The time-series plots display selected water-quality values associated with the 45 discrete in-stream measurements overlain on time-series plots of measured or modeled continuous daily average flows. The scatter plots display the same water-quality constituents, but with respect to the daily average flow at the time of the water-quality measurements. The daily average flows in the time-series and scatter plots can reflect measured data at the New Holland streamflowgaging station or simulated flows from VELMA, GBMM, and TOPMODEL. There are 48 water-quality constituents associated with the discrete in-stream water-quality measurements at New Holland. A dropdown menu was incorporated into the data viewer so that the trends for a selected water-quality constituent, with respect to the hydrologic components, could be displayed one parameter at a time in the time-series and scatter plots. Time-series plots of the relation for total mercury to measured flows and to TOPMODEL simulated flows at
New Holland are shown in figures 4 and 5, respectively. The time-series plots are helpful in displaying the antecedent and current flow conditions associated with selected water-quality measurements and can give insights to hydrologic conditions that promote the observed water-quality trends.

Chemical, biological, and hydrologic processes within an ecosystem can display seasonal trends. Therefore, the waterquality data for the time-series plots and scatter plots were grouped by the dormant and growing seasons. The growing season data are identified by solid green circles and the dormant (or non-growing) season data are identified by solid light blue circles (figs. 4-7). The scatter plots display waterquality trends associated with concurrent flow conditions (measured and modeled) and can help indicate if the waterquality constituent of interest displays a trend associated with flow. In particular, the scatter plots identify influences from surface and subsurface flow components, indicating potential sources for the water-quality constituent of interest. Examples of scatter plots in figure 6 show the relation of total mercury to measured and simulated flows at the New Holland streamflowgaging station.

\section{Comparison Plots of Selected Model Simulations}

For the McTier Creek watershed mercury investigation, six hydrologic and (or) water-quality models were developed including TOPMODEL, TOPLOAD, TOPLOAD-H, LOADEST, GBMM, and VELMA. To assist in evaluating the performance of these models, time-series plots, similar to figures 4 and 5, were developed in the data viewer to show the simulated flows and water-quality loads of the models with respect to each other as well as to the measured data (figs. 7 and 8). Time-series plots of the simulated streamflows (total flow) at New Holland as determined by the TOPMODEL, GBMM, and VELMA models are shown in figure 7. The measured flow at this streamflow-gaging station also is included in the plot. As evidenced, the patterns indicate that each model is capturing the general trends of flow at New Holland.

Evaluating the performance of the models for simulating the hydrology of the McTier Creek watershed provides insight on the performance of the models for simulating loads into the stream ecosystem. The "Load" spreadsheet allows users to visualize the measured and simulated loads from TOPLOAD, TOPLOAD-H, LOADEST, GBMM, and VELMA. A timeseries plot of the simulated mass flux (or load) for total mercury as determined by the TOPLOAD-H, LOADEST, GBMM, and VELMA models is shown in figure 8. The field estimated load associated with the water-quality measurement also is included in the plot. 
Table 4. Description of selected worksheets and applications included in the McTier Creek Data Viewer.

[TOPMODEL, Topography-based hydrological model; TOPLOAD, Water-quality load model developed from TOPMODEL; TOPLOAD-H, Water-quality load model developed from TOPMODEL with Hornberger's ground-water partitioning algorithm; GBMM, Grid-Based Mercury Model; VELMA, Visualizing Ecosystems for Land Management Assessment Model; LOADEST, LOAD ESTimator model]

\begin{tabular}{|c|c|}
\hline Worksheet Name & Description \\
\hline Title Sheet & Title sheet for data viewer. \\
\hline ReleaseNotes & $\begin{array}{l}\text { References and selected information associated with hydrologic and } \\
\text { water-quality models used in the data viewer and a description of } \\
\text { each worksheet in the data viewer. }\end{array}$ \\
\hline Chart (Hydrology) & $\begin{array}{l}\text { Time-series plot comparing simulated flows from TOPMODEL, } \\
\text { GBMM, and VELMA with measured flows, along with concentra- } \\
\text { tion of selected water-quality constituent by season. (Note: Drop- } \\
\text { down menus allow the user to select the model flow components } \\
\text { and water-quality constituent of interest for display.) }\end{array}$ \\
\hline QW Scatter Plots & $\begin{array}{l}\text { Scatter plots for measured water-quality constituents with respect to } \\
\text { selected simulated and measured flows. (Note: A dropdown menu } \\
\text { allows the user to select the water-quality constituent of interest } \\
\text { for display.) }\end{array}$ \\
\hline Chart (Load) & $\begin{array}{l}\text { Time-series plot comparing selected simulated water-quality loads } \\
\text { from TOPLOAD, TOPLOAD-H, LOADEST, GBMM, and VEL- } \\
\text { MA along with measured loads. (Note: Dropdown menus allow } \\
\text { the user to select the load model components and water-quality } \\
\text { constituent of interest for display.) }\end{array}$ \\
\hline Plot Data & $\begin{array}{l}\text { Selected hydrology, water-quality, and load data are stored on this } \\
\text { worksheet and used to generate selected plots in the data viewer. }\end{array}$ \\
\hline Hydrology Data & $\begin{array}{l}\text { Simulated time-series hydrologic output data from TOPMODEL, } \\
\text { GBMM, and VELMA and measured flow associated with stream- } \\
\text { flow-gaging station } 02172305 \text {, McTier Creek near New Holland, } \\
\text { South Carolina. }\end{array}$ \\
\hline QW Data & $\begin{array}{l}\text { Water-quality data for } 48 \text { water-quality constituents associated with } \\
45 \text { discrete measurements collected at streamflow-gaging station } \\
\text { 02172305, McTier Creek near New Holland, South Carolina. }\end{array}$ \\
\hline Load Data & $\begin{array}{l}\text { Simulated water-quality load data for selected water-quality constitu- } \\
\text { ents from TOPLOAD, TOPLOAD-H, LOADEST, GBMM, and } \\
\text { VELMA along with measured loads. }\end{array}$ \\
\hline Chart (TOPLOAD) & $\begin{array}{l}\text { Time-series plot of simulated loads for TOPLOAD along with } \\
\text { measured discrete loads for a selected water-quality constituent. } \\
\text { (Note: An input table allows assignment of water-quality concen- } \\
\text { trations for the TOPLOAD computations.) }\end{array}$ \\
\hline TOPLOAD & $\begin{array}{l}\text { Contains TOPMODEL hydrology data and algorithms used to com- } \\
\text { pute loads for TOPLOAD. }\end{array}$ \\
\hline Chart (TOPLOAD-H) & $\begin{array}{l}\text { Time-series plot of simulated loads for TOPLOAD-H along with } \\
\text { measured discrete loads for a selected water-quality constituent. } \\
\text { (Note: An input table allows assignment of water-quality concen- } \\
\text { trations for the TOPLOAD-H computations.) }\end{array}$ \\
\hline TOPLOAD-H & $\begin{array}{l}\text { Contains TOPMODEL and Hornberger flow component data and } \\
\text { algorithms used to compute loads for TOPLOAD-H. }\end{array}$ \\
\hline Selection Tables & $\begin{array}{l}\text { Provides information used to drive selected dropdown menus and } \\
\text { automated data retrieval in the data viewer. }\end{array}$ \\
\hline Define Flow Parameters & $\begin{array}{l}\text { Provides an illustration defining the surface- and subsurface-flow } \\
\text { components associated with TOPMODEL. }\end{array}$ \\
\hline
\end{tabular}




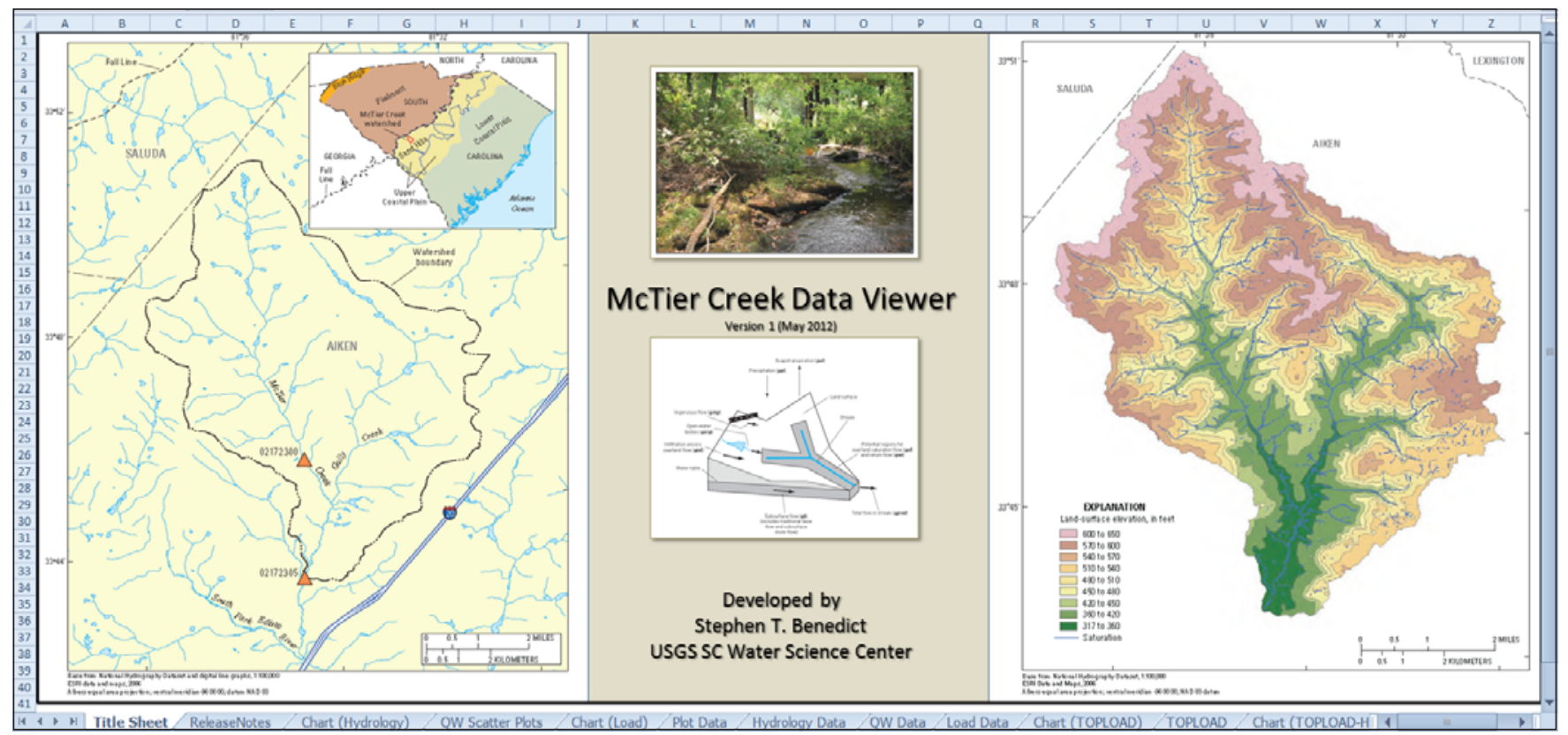

Figure 3. Screen capture from the McTier Creek Data Viewer showing "Title Sheet" worksheet.

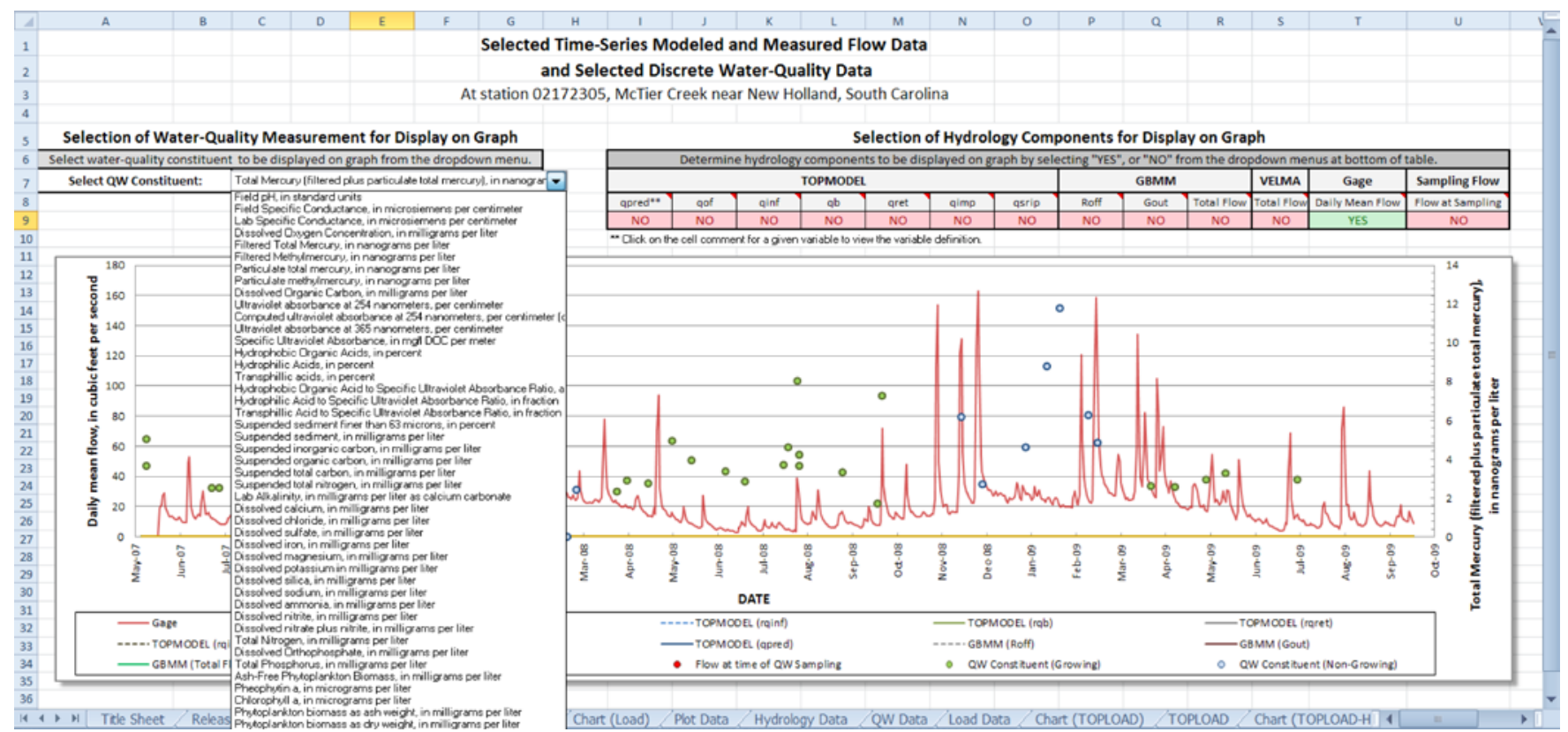

Figure 4. Screen capture from the TOPMODEL worksheet showing dropdown menu of selected constituent to be shown with the measured flow data. 


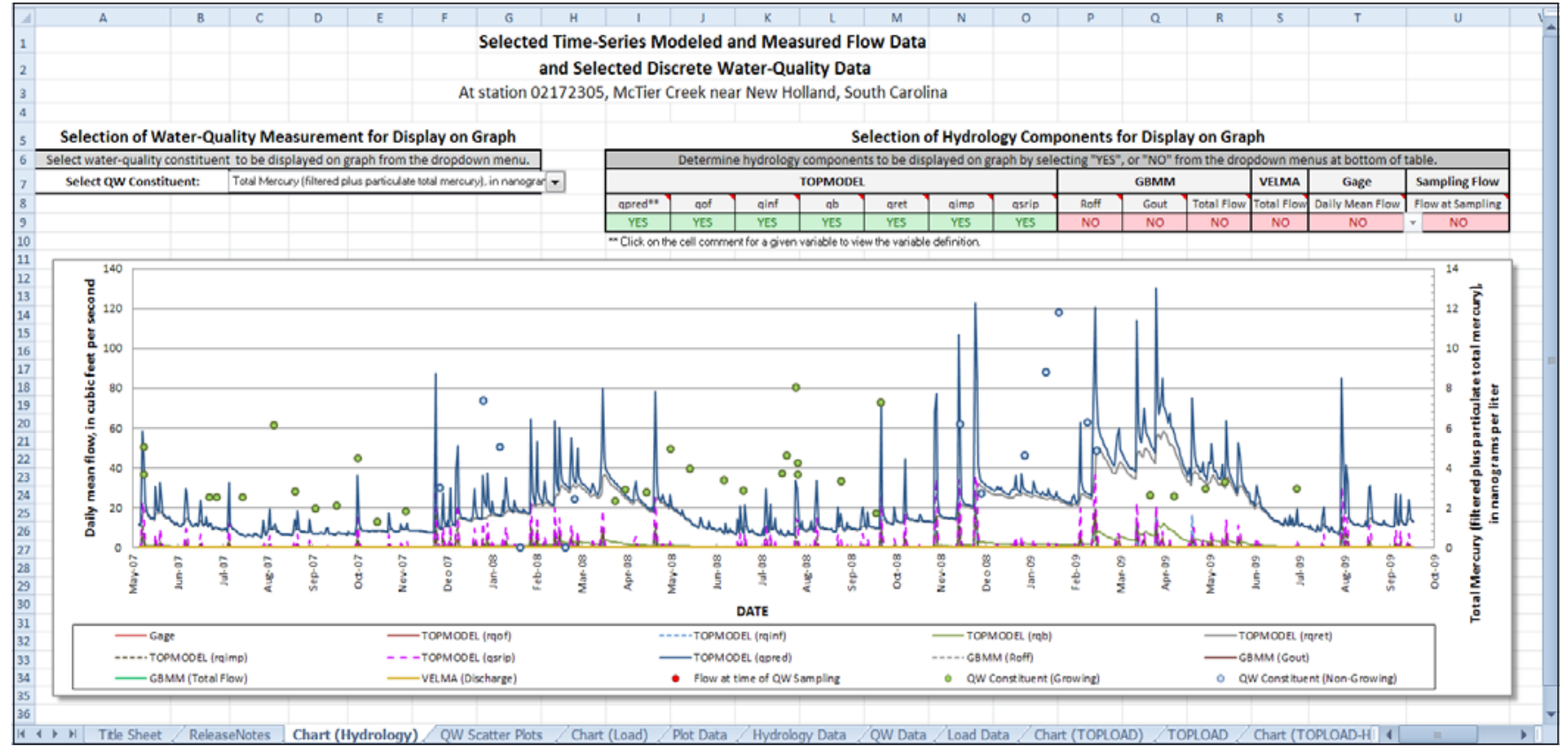

Figure 5. Screen capture from the TOPMODEL worksheet showing selected constituent concentration with the TOPMODEL simulated flow components.

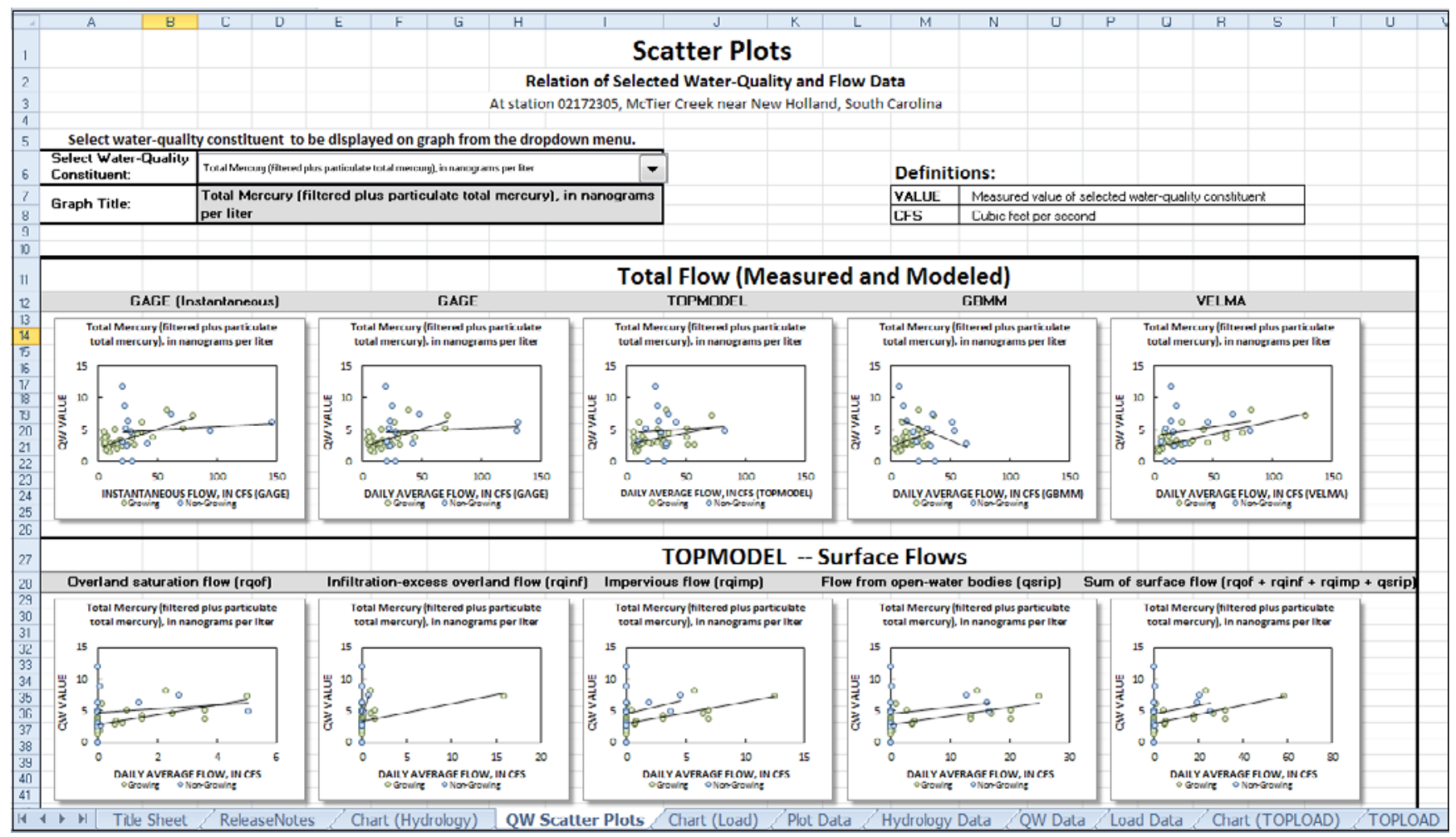

Figure 6. Screen capture from the scatter plot worksheet showing scatter plots of the selected constituent and various measured flow and simulated flow components. 


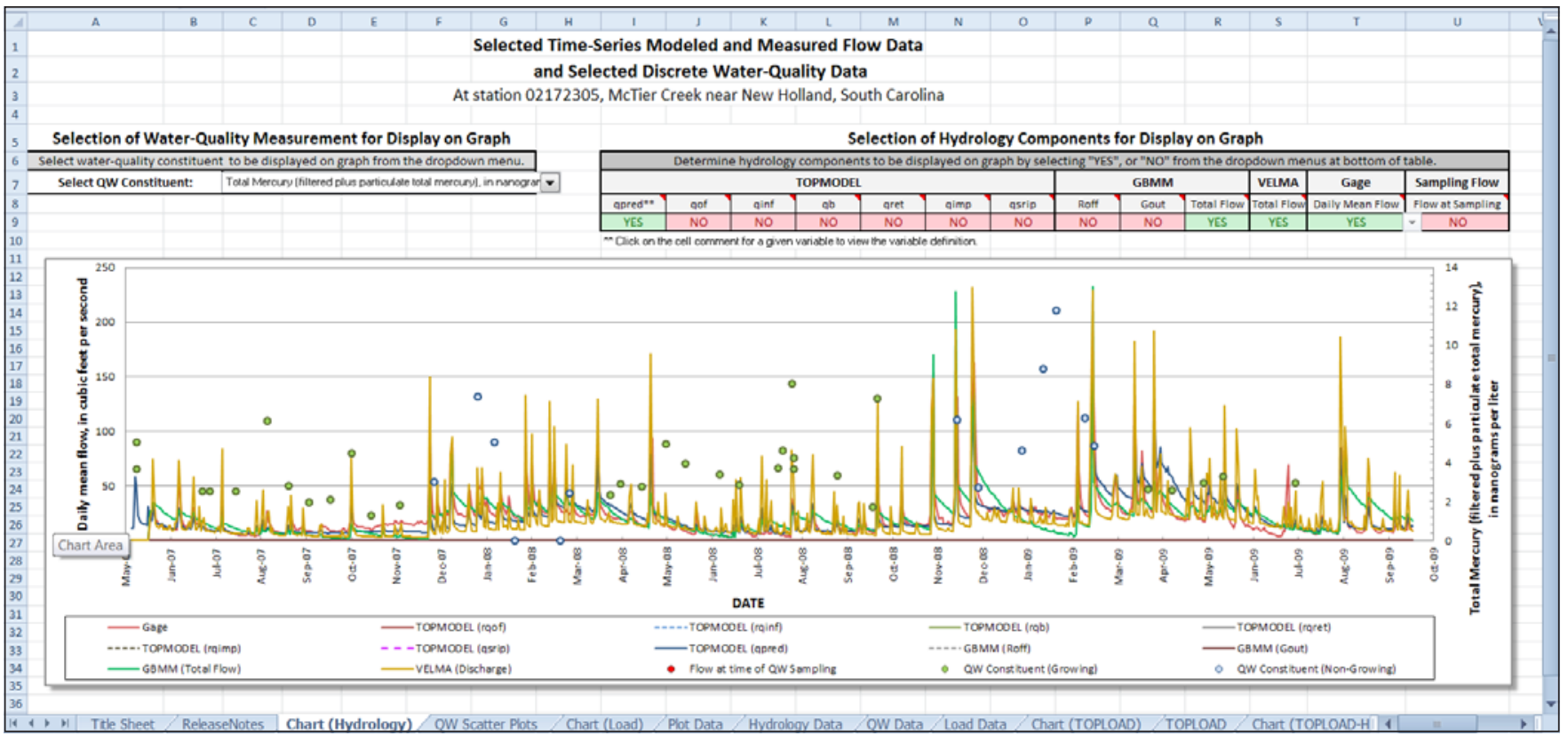

Figure 7. Screen capture from the model comparison worksheet showing the measured and simulated flows from TOPMODEL, GBMM, and VELMA along with the selected constituent by season.

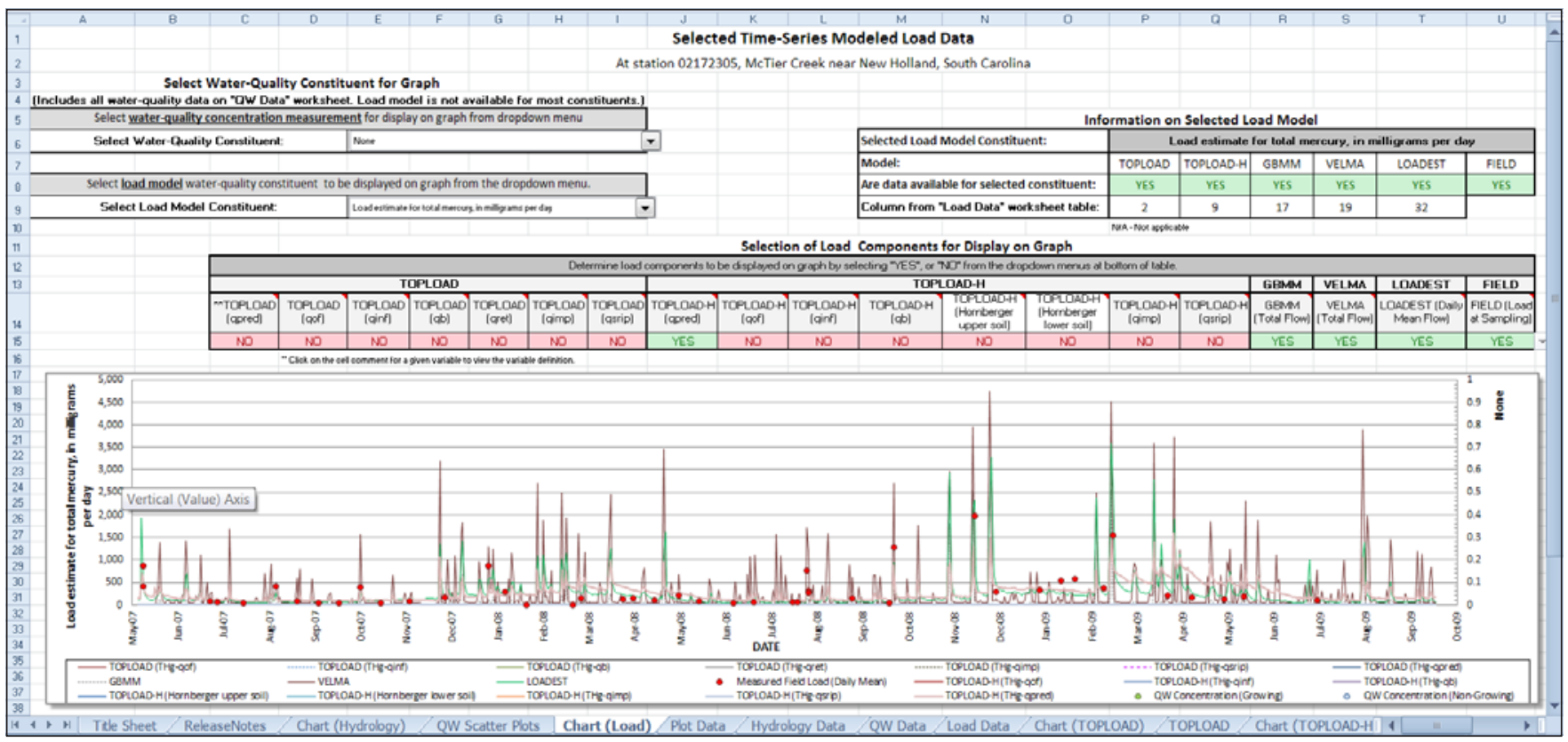

Figure 8. Screen capture from the model comparison worksheet showing the measured and simulated loads from TOPLOAD-H, LOADEST, GBMM, and VELMA. 


\section{Summary}

The U.S. Geological Survey, as part of its National Water-Quality Assessment Program, has been conducting research regarding the fate and transport of mercury in stream ecosystems. Part of this national research program includes a field investigation of mercury in the McTier Creek watershed in Aiken County, South Carolina. McTier Creek is a small stream ecosystem in the headwaters of the Edisto River Basin, which is noted for having some of the highest recorded fishtissue mercury concentrations in the United States. A primary focus of this investigation was the collection of field data and the development of hydrologic and water-quality models. These efforts yielded an extensive quantity of data including continuous streamflow records, numerous discrete waterquality measurements, and simulated data from six hydrologic and (or) water-quality models. These data provide a valuable resource for investigating the chemical, biological, and hydrologic characteristics that influence the fate and transport of mercury in stream ecosystems.

Because of the large quantity of data associated with the McTier Creek watershed investigation, a tool to quickly and easily visualize the measured and simulated hydrologic and water-quality data was considered an important resource for investigating the trends and influencing variables of the stream ecosystem. Therefore, one of the initial efforts for evaluating trends in the McTier Creek watershed was the development of a data viewer consisting of a set of digital spreadsheets for systematically visualizing selected hydrologic, water-quality, and model data. The general description of the data viewer provided in the report gives an overview of how such a tool can be developed and demonstrates through sample plots some benefits that can be derived from the data viewer with regard to visualizing trends associated with the McTier Creek watershed mercury investigation.

The extensive database incorporated into the data viewer can provide a foundation for the development of other analysis tools. One example of utilizing the data viewer in this manner was the development of the TOPLOAD and TOPLOAD-H models. These models utilize a mass-balance equation in conjunction with the hydrologic simulations from the McTier Creek TOPMODEL (data included in the data viewer) to develop simple water-quality load models. The overview for the development of these models in the appendix provides a general approach for how other analysis tools and (or) models might be developed with the data viewer. 


\section{Selected References}

Aucott, W.R., and Speiran, G.K., 1985, Ground-water flow in the Coastal Plain aquifers of South Carolina: Ground Water, v. 23 , p. 736-745.

Bennett, D.G., and Patton, J.C., eds., 2008, A geography of the Carolinas: Boone, North Carolina, Parkway Publishers, $266 \mathrm{p}$.

Bloxham, W.M., 1976, Low-flow characteristics of streams in the Inner Coastal Plain of South Carolina: South Carolina Water Resources Commission Report No. 5, 41 p.

Bradley, P.M., Burns, D.A., Riva-Murray, Karen, Brigham, M.E., Button, D., Chasar, L.C., Marvin-DiPasquale, M., Lowery, M.A., and Journey, C.A., 2011, Spatial and seasonal variability of dissolved methylmercury in two stream basins in the eastern United States: Environmental Science and Technology, v. 46, no. 6, p. 2048-2055, doi: 10.1021/ es103923j.

Bradley, P.M., Chapelle, F.H., and Journey, C.A., 2009, Comparison of methylmercury production and accumulation in sediments of the Congaree and Edisto River Basins, South Carolina, 2004-06: U.S. Geological Survey Scientific Investigations Report 2009-5021, 9 p.

Bradley, P.M., Journey, C.A., Chapelle, F.H., Lowery, M.A., and Conrads, P.A., 2010, Flood hydrology and methylmercury availability in Coastal Plain rivers. Environmental Science and Technology, v. 44 no. 24, p. 9285-9290.

Brigham, M.E., Krabbenhoft, D.P., and Hamilton, P.A., 2003, Mercury in stream ecosystems-New studies initiated by the U.S. Geological Survey: U.S. Geological Fact Sheet 016-03, 4 p.

Brigham, M.E., Wentz, D.A., Aiken, G.R., and Krabbenhoft, D.P., 2009, Mercury cycling in stream ecosystems, 1, Water column chemistry and transport: Environmental Science and Technology, v. 43, no. 8, p. 2720-2725.

Chasar, L.C., Scudder, B.C., Stewart, A.R., Bell, A.H., and Aiken, G.R., 2009, Mercury cycling in stream ecosystems, 3, Trophic dynamics and methylmercury bioaccumulation: Environmental Science and Technology, v. 43, no. 8, p. 2733-2739.

Cohn, T.A., 2005, Estimating contaminant loads in riversAn application of adjusted maximum likelihood to type 1 censored data: Water Resources Research, v. 41, W07003, doi:10.1029/2004WR003833.

Cohn, T.A., Caulder, D.L., Gilroy, E.J., Zynjuk, L.D., and Summers, R.M., 1992, The validity of a simple statistical model for estimating fluvial constituent loads - An empirical study involving nutrient loads entering Chesapeake Bay: Water Resources Research, v. 28, no. 9, p. 2353-2363.
Cooke, C.W., 1936, Geology of the Coastal Plain of South Carolina: U.S. Geological Survey Bulletin 867, 196 p.

Dai, T., Ambrose, R.B., Alvi, K., Wool, T., Manguerra, H., Choski, M., Yang, H., and Kraemer, S., 2005, Characterizing spatial and temporal dynamics - Development of a grid-based watershed mercury loading model, in Moglen, G.E., (ed.), Managing watersheds for human and natural impacts-Engineering, ecological, and economic challenges, Williamsburg, Virginia, July 19-22, 2005: Reston, Virginia, American Society of Civil Engineers.

DeWild, J.F., Olson, M.L., and Olund, S.D., 2001, Determination of methyl mercury by aqueous phase ethylation, followed by gas chromatographic separation with cold vapor atomic fluorescence detection: U.S. Geological Survey Open-File Report 01-445, 14 p.

Dunne, T., and Black, R.D., 1970, Partial area contributions to storm runoff in a small New England watershed: Water Resources Research, v. 6, p. 1296-1311.

Eidson, J.P., Lacy, C.M., Nance, Luke, Hansen, W.F., Lowery, M.A., and Hurley, N.M., Jr., 2005, Development of a 10and 12-digit hydrologic unit code numbering system for South Carolina, 2005: U.S. Department of Agriculture, Natural Resources Conservation Service, 38 p., 1 pl.

Feaster, T.D., Golden, H.E., Odom, K.R., Lowery, M.A., Conrads, P.A., and Bradley, P.M., 2010, Simulation of streamflow in the McTier Creek watershed, South Carolina: U.S. Geological Survey Scientific Investigations Report 2010-5202, 61 p.

Golden, H.E., and Knightes, C.D., 2011, Simulated watershed mercury and nitrate flux responses to multiple land cover conversion scenarios-Environmental Toxicology and Chemistry, v. 30, no. 4, p. 773-786.

Golden, H.E., Knightes, C.D., Cooter, E.J., Dennis, R.L., Gilliam, R.C., and Foley, K.M., 2010, Linking air quality and watershed models for environmental assessments: Analysis of the effects of model-specific precipitation estimates on calculated water flux - Environmental Modeling \& Software, v. 25, no. 12, p. 1722-1737.

Golden, H.E., Knightes, C.D., Conrads, P.A., Davis, G.M., Feaster, T.D., Journey, C.A., Benedict, S.T., Brigham, M.E., and Bradley, P.M., 2012, Characterizing mercury concentrations and fluxes in a Coastal Plain watershed: Insights from dynamic modeling and data, Journal of Geophysical Research, 117, 17 pp., doi:10.1029/2011JG001806.

Griffith, G.E., Omernik, J.M., Comstock, J.A., Schafale, M.P., McNab, W.H., Lenat, D.R., MacPherson, T.F., Glover, J.B., and Shelburne, V.B., 2002, Ecoregions of North Carolina and South Carolina-U.S. Geological Survey color poster with map, scale 1:1,500,000. 
Grigal, D.F., 2002, Inputs and outputs of mercury from terrestrial watersheds: A review: Environmental Reviews, no. 10 , p. 1-39.

Helsel, D.R., 2005, Nondetects and data analysis-Statistics for censored environmental data: New Jersey, WileyInterscience, $250 \mathrm{p}$.

Helsel, D.R., and Hirsch, R.M., 1992, Statistical methods in water sources: U.S. Geological Survey Techniques of Water Resources Investigations, book 4, chap., A3, 512 p.

Homer, C., Huang, C., Yang, L., Wylie, B.K., and Coan, M., 2004, Development of a 2001 National Landcover Database for the United States: Photogrammetric Engineering and Remote Sensing, v. 70, p. 829-840.

Hornberger, G.M., Bencala, K.E., and McKnight, D.M., 1994, Hydrological controls on dissolved organic carbon during snowmelt in the Snake River near Montezuma, Colorado: Biogeochemistry, v. 25, p. 147-165.

Hornberger, G.M., Raffensperger, J.P., Wiberg, P.L., and Eshleman, K.N., 1998, Elements of physical hydrology: Baltimore, Maryland, The John Hopkins University Press.

Journey, C.A., Burns, D.A., Riva-Murray, K., Brigham, M.E., Button, D., Feaster, T.D., Petkewich, M.D., and Bradley, P.M., 2012, Fluvial transport of mercury, organic carbon, suspended sediment, and selected major ions in contrasting stream basins in South Carolina and New York, October 2004 to September 2009: U.S. Geological Survey Scientific Investigations Report 2012-5173, 125 p.

Krabbenhoft, D.P., Wiener, J.G., Brumbaugh, W.G., Olson, M.L., DeWild, J.F., and Sabin, T.J., 1999, A national pilot study of mercury contamination of aquatic ecosystems along multiple gradients; in Morganwalp, D.W., and Buxton, H.T., eds., U.S. Geological Survey Toxic Substances Hydrology Program-Proceedings of the Technical Meeting, Volume 2 of 3 - Contamination of hydrologic systems and related ecosystems, March 8-12, 1999, Charleston, South Carolina: U.S. Geological Survey WaterResources Investigations Report 99-4018B, p. 147-160.

Lewis, M.E., and Brigham, M.E., 2004, National field manual for the collection of water-quality data, section 5.6.4.B, Low-level mercury: U.S. Geological Survey Techniques of Water-Resources Investigations Report, book 9, chap. A5.

Lorenz, D.L., and others, 2011, USGS library for S-PLUS for Windows-Release 4.0: U.S. Geological Survey Open-File Report 2011-1130.

Marshall, W.D., ed., 1993, Assessing change in the Edisto River Basin-An ecological characterization: South Carolina Water Resources Commission Report No. 177, 149 p.
Mergler, D., Anderson, H.A., Chan L.H.M., Mahaffey, K.R., Murray, M., Sakamoto, M., and Stern, A.H., 2007, Methylmercury exposure and health effects in humans - A worldwide concern: Ambio, v. 36, no. 1, p. 3-11.

National Land Coverage Data (NLCD), 2001, Multi-resolution land characteristics consortium (MRLC): Accessed at http:// www.epa.gov/mrlc/nlcd-2001.html.

Rantz, S.E., and others, 1982, Measurement and computation of streamflow: U.S. Geological Survey Water-Supply Paper 2175, v. 2, 631 p.

Robson, A., Beven, K., and Neal, C., 1992, Towards identifying sources of subsurface flow-A comparison of components identified by a physically based runoff model and those determined by chemical mixing techniques: Hydrologic Processes, v. 6, p. 199-214.

Runkel, R.L., Crawford, C.G., and Cohn, T.A., 2004, Load estimator (LOADEST) -A FORTRAN program for estimating constituent loads in streams and rivers: U.S. Geological Survey Techniques and Methods, book 4, chap. A5, 69 p.

Scudder, B.C., Chasar, L.C., Wentz, D.A., Bauch, N.J., Brigham, M.E., Moran, P.W., and Krabbenhoft, D.P., 2009, Mercury in fish, bed sediment, and water from streams across the United States, 1998-2005: U.S. Geological Survey Scientific Investigations Report 2009-5109, 74 p.

Swain, E.B., Jakus, P.M., Rice, G., Lupi, F., Maxson, P.A., Pacyna, J.M., Penn, A., Spiegel, S.J., and Veiga, M.M., 2007, Socioeconomic consequences of mercury use and pollution: Ambio, v. 36, no. 1, p. 45-61.

U.S. Environmental Protection Agency, 2008, Biennial national listing of fish advisories: Report EPA823-F-09-007, 7 p.

Vigil, J.F., Pike, R.J., and Howell, D.G., 2000, A tapestry of time and terrain: U.S. Geological Survey Geologic Investigations Series 2720 .

Whipkey, R.Z., 1965, Subsurface stormflow from forested slopes: Hydrological Sciences Bulletin, v. 10, p. 74-85.

Wiener, J.G., Krabbenhoft, D.P., Heinz, G.H., and Scheuhammer, A.M., Ecotoxicology of mercury, Chapter 16; in Hoffman, D.J., Rattner, B.A., Burton, G.A., Jr., and Cairns, J., Jr., Handbook of ecotoxicology (2nd ed.): Boca Raton, Florida, CRC Press.

Wolock, D.M., 1993, Simulating the variable-source-area concept of streamflow generation with the watershed model TOPMODEL: U.S. Geological Survey Water-Resources Investigations Report 93-4124, 33 p. 


\section{Appendix}

\section{Mass-Balance Model}

The surface and subsurface flow components of an ecosystem that combine to form the total in-stream flow will typically have their own unique water-quality properties. The water quality of these flow components is partially a function of the path that each component takes to reach the stream, with surface flows having their water-quality characteristics influenced by the flow path along the land surface and subsurface flows having their characteristics influenced by the flow path through the soil matrix. Studies by Hornberger and others (1994; 1998) and Robson and others (1992) indicate that the land surface can function as a storage reservoir for waterquality constituents delivered through atmospheric deposition and natural processes, whereas the subsurface soil matrix can function as a storage reservoir for selected constituents that are leached into the soils through infiltration. Because of the long retention times often associated with subsurface flows, it is possible that the deeper subsurface flow components can have relatively high water-quality concentrations for selected constituents. Together the surface and subsurface mass flux (or load) combines to form the water-quality characteristics of the streamflow. Therefore, in order to evaluate and understand the in-stream water quality of an ecosystem, it is important to assess the various surface and subsurface flow components and their respective water-quality characteristics.

To define the surface and subsurface flow components of a watershed, one must primarily rely on hydrologic models and accept the limitations associated with those models. For this particular application to the McTier Creek watershed, the TOPMODEL (Wolock, 1993; Feaster and others, 2010) was used to accomplish this task. Although other models could be used, an objective of the investigation was to evaluate the potential use of the hydrologic model TOPMODEL as a water-quality load model. To define the water-quality characteristics (or more specifically, the concentration of selected constituents) associated with each flow component, one must rely on limited field measurements and judgment to estimate these values. A review of the water-quality field data collected in the McTier Creek watershed was utilized for this purpose. Although each watershed will have unique considerations in the assignment of constituent concentrations associated with the various surface and subsurface flow components, the studies by Hornberger and others $(1994 ; 1998)$ and Robson and others (1992) provide practical insights on how this assignment can be accomplished. Having defined the surface and subsurface flow components and their respective concentrations for selected water-quality constituents, these data can be combined to develop a mass-balance model based on the principle of the conservation of mass.
A general mass-balance equation for a given waterquality constituent in a stream ecosystem can be expressed as,

$$
\frac{d M}{d t}=K Q_{s u b} C_{s u b}+K Q_{s u r f} C_{s u r f}-K Q_{s t r} C_{s t r}+\sum s+\sum r
$$

where

$$
\begin{aligned}
& \frac{d M}{d t} \quad \text { is rate of change of mass for the water-quality } \\
& \text { constituent within the stream ecosystem, in } \\
& \text { milligrams per day; } \\
& K \quad \text { is unit conversion coefficient equal to } 2.447 \text {; } \\
& Q_{\text {sub }} \quad \text { is flow associated with subsurface flow, in } \\
& \text { cubic feet per second; } \\
& C_{\text {sub }} \text { is concentration of the water-quality } \\
& \text { constituent associated with subsurface } \\
& \text { flow, in nanograms per liter; } \\
& Q_{\text {surf }} \quad \text { is flow associated with surface flow, in cubic } \\
& \text { feet per second; } \\
& C_{\text {surf }} \text { is concentration of the water-quality } \\
& \text { constituent associated with surface flow, in } \\
& \text { nanograms per liter; } \\
& Q_{\text {str }} \quad \text { is flow associated with the total in-stream } \\
& \text { flow, in cubic feet per second; } \\
& C_{s t r} \quad \text { is concentration of the water-quality } \\
& \text { constituent associated with the total in- } \\
& \text { stream flow, in nanograms per liter; } \\
& s \quad \text { is rate at which the mass of the water-quality }
\end{aligned}
$$

It should be noted that units for concentration can vary with water-quality constituent requiring an adjustment to the unit conversion coefficient, $K$, in order to maintain equation units. This applies to all equations listed in the appendix.

If steady-state conditions for the rate of change of mass within the ecosystem are assumed, equation A1 simplifies to the following:

$$
Q_{s t r} C_{s t r}=Q_{s u b} C_{s u b}+Q_{s u r f} C_{s u r f}
$$

Equation A2 is a simple but useful tool that can be applied in various ways to investigate the separation of hydrograph flow components, identify potential sources for a given water-quality constituent, and develop water-quality load models. For many field investigations, the variables on the left side of equation A2 can be defined with standard field measurement techniques. The variables on the right side of the equation are more challenging to define. To define the surface and subsurface flow components in equation A2, hydrologic models, such as the TOPMODEL, must be used. With 
definition of these flow components, the water-quality concentrations associated with the surface and subsurface flows can then be evaluated, and insights regarding water-quality sources within the ecosystem can be gained. If the constituent concentrations on the right side of the equation can be approximated through a combination of field measurements and judgment, then it is possible to approximate the surface and subsurface hydrographs that form the in-stream flow, giving insights into the hydrology of the ecosystem. Additionally, if all of the variables on the right side of equation A2 can be defined, the water-quality constituent load can be estimated and the equation becomes a simple load model. The studies by Hornberger and others $(1994 ; 1998)$ and Robson and others (1992) provide practical insights on how varying forms of equation A2 can be applied to field conditions for assessing the hydrology and water quality of an ecosystem.

\section{TOPLOAD Model}

One objective of the current (2011) McTier Creek investigation is to utilize the mass-balance equation (eq. A2) in combination with the TOPMODEL hydrologic simulation to develop a load model for selected water-quality constituents in the McTier Creek watershed. To apply equation A2 to the TOPMODEL flow components, the equation must be expanded to include additional terms for the surface (qinf, qimp, qsrip, qof) and subsurface ( $q b$, qret) flow components in the model, as shown in equation A3 (see "TOPMODEL" section in report for definition of flow components):

$$
\begin{aligned}
Q_{s t r} C_{s t r}= & Q_{q b} C_{q b}+Q_{q r e t} C_{q r e t}+Q_{q i n f} C_{q i n f} \\
& +Q_{q i m p} C_{q i m p}+Q_{q s i p} C_{q s i p}+Q_{q o f} C_{q o f},
\end{aligned},
$$

where

$Q_{q b} \quad$ is subsurface base flow from TOPMODEL, in cubic feet per second;

$C_{q b} \quad$ is water-quality constituent concentration for subsurface base flow, in nanograms per liter;

$Q_{\text {qret }} \quad$ is subsurface return flow from TOPMODEL, in cubic feet per second;

$C_{\text {qret }}$ is water-quality constituent concentration for subsurface return flow, in nanograms per liter;

$Q_{\text {qinf }} \quad$ is surface infiltration-excess overland flow from TOPMODEL, in cubic feet per second;

$C_{\text {qinf }}$ is water-quality constituent concentration for surface infiltration-excess overland flow, in nanograms per liter;

$Q_{\text {qimp }}$ is surface impervious flow from TOPMODEL, in cubic feet per second;

$C_{\text {qimp }} \quad$ is water-quality constituent concentration for surface impervious flow, in nanograms per liter;

$Q_{q s r i p} \quad$ is surface open-water body flow from TOPMODEL, in cubic feet per second

$C_{q s i p} \quad$ is water-quality constituent concentration for surface open-water body flow, in nanograms per liter;

$Q_{\text {gof }} \quad$ is surface overland saturation flow from TOPMODEL, in cubic feet per second; and

$C_{q o f} \quad$ is water-quality constituent concentration for surface overland saturation flow, in nanograms per liter.

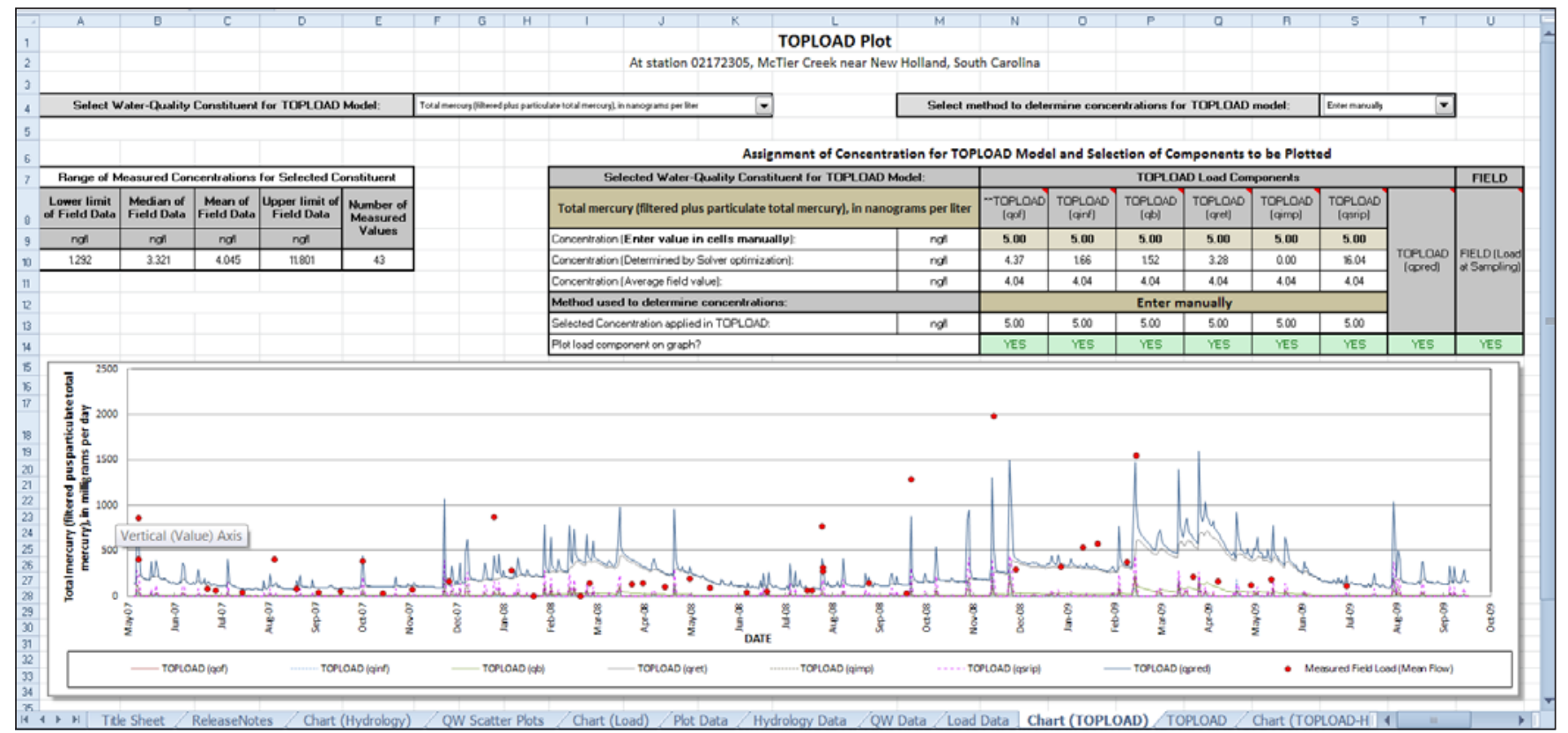

Figure A1. Screen capture from the TOPLOAD worksheet showing input table for manually assigning concentrations to the TOPMODEL flow components. 
If the hydrologic and water-quality components on the right side of equation $\mathrm{A} 3$ are estimated with TOPMODEL and water-quality field measurements, respectively, and applied to equation $\mathrm{A} 3$, then the result (left side of equation A3) represents the predicted load for a given constituent. In this application, equation $\mathrm{A} 3$ becomes a simple model for evaluating loads and will be called the TOPLOAD model.

To apply equation $\mathrm{A} 3$, the time-series output data for TOPMODEL must be imported into a spreadsheet and the flow components organized into a tabular format. Because the McTier Creek Data Viewer (see description in "Features of the McTier Creek Data Viewer" section in report) already contained the TOPMODEL output data, it was used as the initial spreadsheet for developing the load model. Concentrations for the constituent of interest must then be assigned to each flow component and tabulated in the spreadsheet. TOPLOAD provides two methods for assigning water-quality concentrations to each flow component. One method allows the user to manually assign these values on the worksheet (fig. A1) that contains the time-series plot of the simulated loads, so that the effect of the assigned concentration can be readily observed. The other method automates the process through an algorithm that utilizes the Excel Solver to determine the assigned waterquality concentrations that minimize the root mean square error between predicted and observed loads. For the initial application of the TOPLOAD model to McTier Creek watershed, it was assumed that the concentrations for a given flow component would be constant. The validity of this assumption probably varies with water-quality constituent and flow component and will likely need further investigation. However, for initial applications of TOPLOAD to the McTier Creek watershed, the assumption is not an unreasonable approach as shown by the work of Hornberger and others $(1994 ; 1998)$ and Robson and others (1992). Using standard spreadsheet applications, the loads for each flow component on the right side of equation $\mathrm{A} 3$ were computed and then summed to predict the total load, as represented by the left side of the equation. This computation is applied to each time-series step (1 day) for the TOPMODEL output that extends during the period from June 2007 through August 2009.

In order to evaluate the performance of the TOPLOAD model, the hydrologic and water-quality field measurements collected at the New Holland streamflow-gaging station were used to estimate the measured loads. Using the 45 discrete in-stream water-quality measurements in conjunction with the average daily streamflow collected at New Holland, the average daily field loads associated with the day of the measurements can be computed and compared with the TOPLOAD model. A time-series plot of the TOPLOAD load estimates along with the field measured loads for total mercury are shown in figure A1.

\section{TOPLOAD-H Model}

Hornberger and others (1994) presented a mass-balance conceptual model consisting of three flow components including overland (or surface) flow and a lower and upper soil flow component. The conceptual model assumes that the breakpoint between the upper and lower soil zones is approximately the perennial water table (fig. A2). As water rises into the upper soil zone, that portion of the subsurface flow will acquire water-quality characteristics different from those of the lower soil zone. This conceptual model is presented in equation A4 and is similar in form to equation A2.

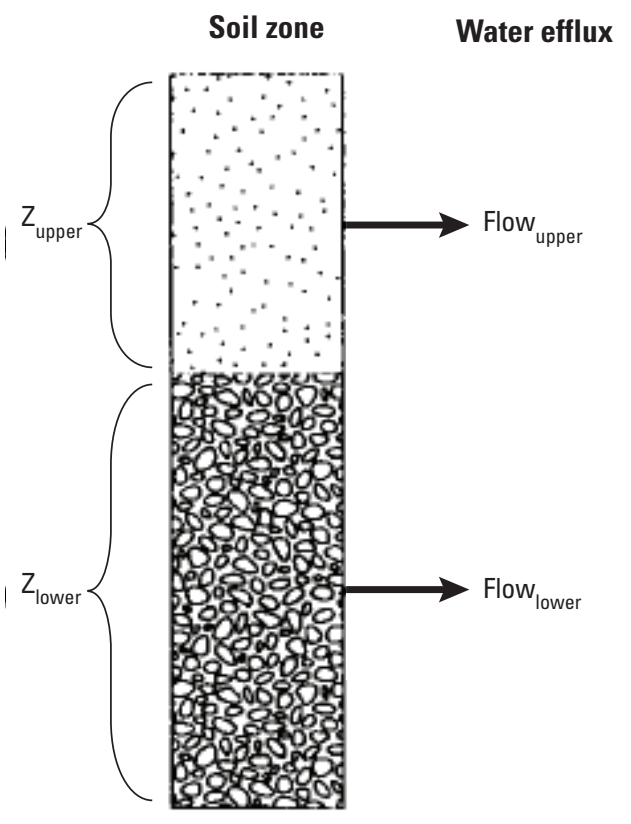

Figure A2. Schematic showing the partitioning of the ground-water flow component (from Hornberger and others, 1994).

$$
Q_{s t r} C_{s t r}=Q_{\text {over }} C_{\text {over }}+Q_{\text {lower }} C_{\text {lower }}+Q_{\text {upper }} C_{\text {upper }} \text {, }
$$

where

$Q_{\text {over }} \quad$ is flow associated with overland (or surface) flow, in cubic feet per second;

$C_{\text {over }}$ is concentration of water-quality constituent associated with overland (or surface) flow, in nanograms per liter;

$Q_{\text {lower }} \quad$ is the flow associated with a lower soil zone, in cubic feet per second;

$C_{\text {lower }} \quad$ is concentration of water-quality constituent associated with a lower soil zone, in nanograms per liter;

$Q_{\text {upper }} \quad$ is flow associated with an upper soil zone, in cubic feet per second; and

$C_{\text {upper }} \quad$ is concentration of water-quality constituent associated with an upper soil zone, in nanograms per liter. 
To estimate $Q_{\text {lower }}$ and $Q_{\text {upper }}$ at a given time, Hornberger and others (1994) suggest the following equation:

$$
Q_{\text {upper }}=Q_{\text {sub }}\left(n z_{\text {upper }}-S\right) /\left(n z_{\text {total }}-S\right) \text {, }
$$

where

$Q_{\text {sub }} \quad$ is flow associated with subsurface flow and is equal to the sum of $Q_{\text {upper }}$ and $Q_{\text {lower }}$, in cubic feet per second. (Note: In the development of this model it was assumed that $Q_{\text {qret }}$ is equal to $Q_{\text {sub }}$. This assumption allows the TOPMODEL flow component, $Q_{q b}$, to function as a third lower flow zone); $n \quad$ is soil porosity;

$z_{\text {upper }} \quad$ is depth of the upper soil zone, in millimeters; $z_{\text {total }}$ is depth of the total soil zone and equal to the sum of the upper and lower soil zone, in millimeters;

$S \quad$ is saturation deficit, which is the amount of water required to cause the water table to rise to the ground surface, in millimeters (Note: If $S$ is greater than $n z_{\text {upper }}$, then $Q_{\text {upper }}$ is set to zero).
Using selected input and output data from TOPMODEL (Wolock, 1993; Feaster and others, 2010), $Q_{\text {sub }}, S, z_{\text {total }}$ and $n$ can be defined for application to equation A5 leading to an estimate of $Q_{\text {upper }}$ and $Q_{\text {lower }}$. Assuming that $Q_{\text {qret }}$ will be the primary source of flow for the Hornberger upper and lower soil zones, $Q_{\text {upper }}$ and $Q_{\text {lower }}$ can then be substituted for $Q_{\text {qret }}$ in equation $\mathrm{A} 3$ to obtain the following equation:

$$
\begin{aligned}
& Q_{\text {str }} C_{\text {str }}=Q_{q b} C_{q b}+Q_{\text {upper }} C_{\text {upper }}+Q_{\text {lower }} C_{\text {lower }}+Q_{\text {qinf }} C_{\text {qinf }} \\
& +Q_{\text {qimp }} C_{\text {qimp }}+Q_{\text {qsiip }} C_{\text {qsip }}+Q_{\text {qof }} C_{\text {qof }}
\end{aligned}
$$

where

$$
\begin{array}{ll}
C_{\text {upper }} & \begin{array}{l}
\text { is water-quality constituent concentration for } \\
\text { the upper soil flow, in nanograms per liter; } \\
\text { and }
\end{array} \\
C_{\text {lower }} & \begin{array}{l}
\text { is water-quality constituent concentration for } \\
\text { the lower soil flow, in nanograms per liter. }
\end{array}
\end{array}
$$

Using the TOPMODEL data from the McTier Creek Data Viewer and a similar approach for the development of TOPLOAD, equation A6 was applied to the TOPMODEL data to develop another simple model for evaluating loads. This model is called the TOPLOAD-H model. 
For additional information regarding this publication, contact:

Director

USGS South Carolina Water Science Center

Stephenson Center, Suite 129

720 Gracern Road

Columbia, SC 29210-7651

(803) 750-6181

email: dc_sc@usgs.gov

Or visit the USGS South Carolina Water

Science Center Web site at:

http://sc.water.usgs.gov

Prepared by:

USGS Science Publishing Network

Raleigh Publishing Service Center

3916 Sunset Ridge Road

Raleigh, NC 27607 

- I

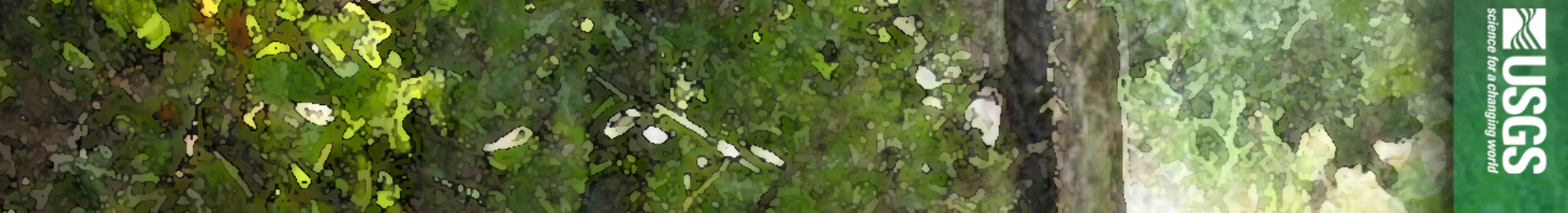

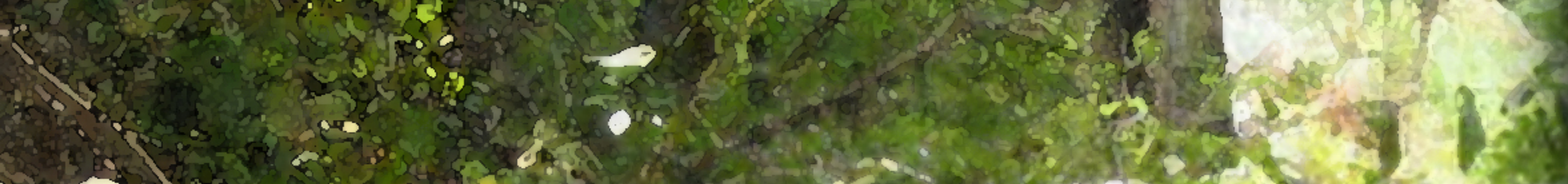

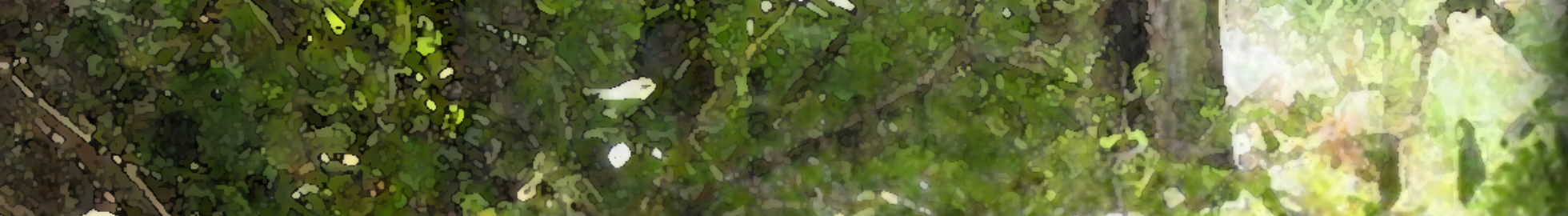

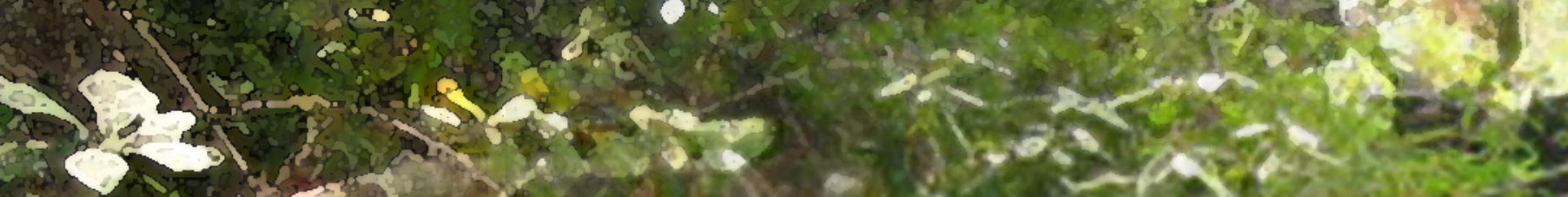

造 1.2.

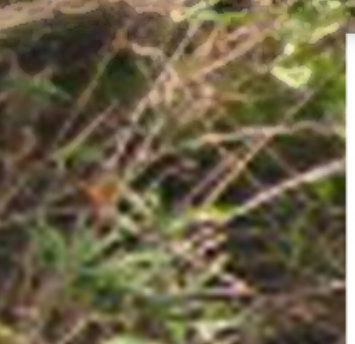

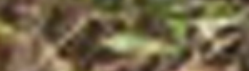

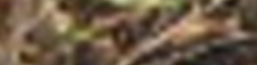

(a)

2

sing s. ract

sats

$\sin 20-20$

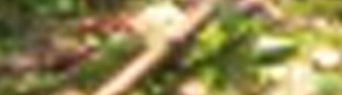

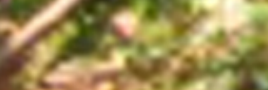

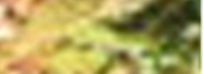

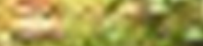

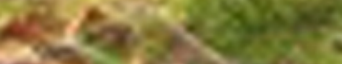

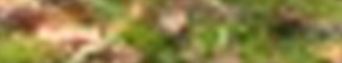

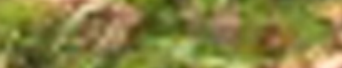

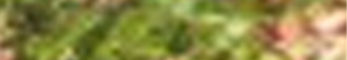

1000

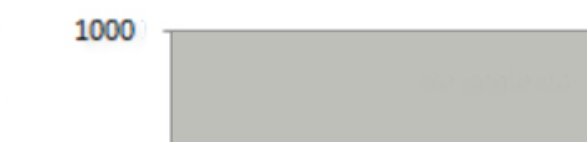

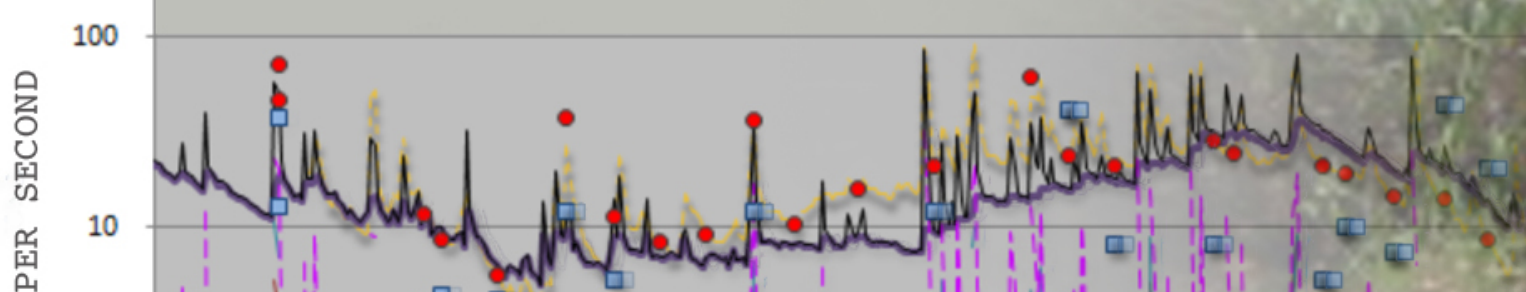

ood

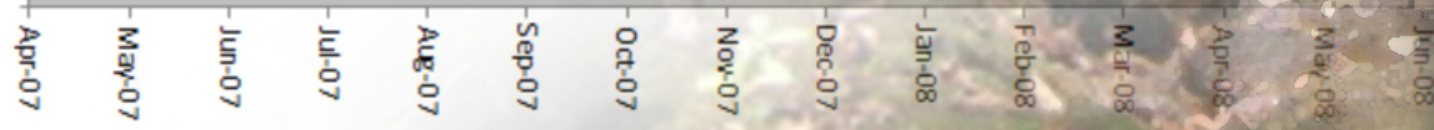

001

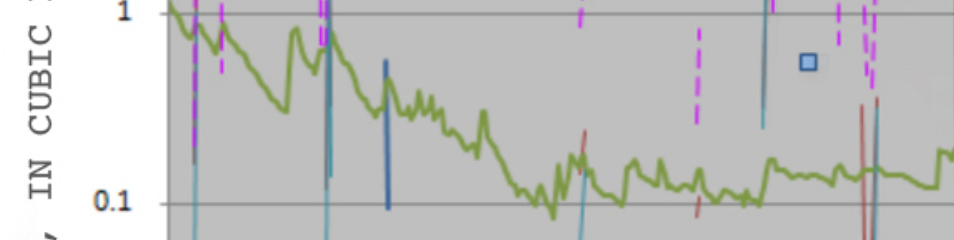

마 맘

1

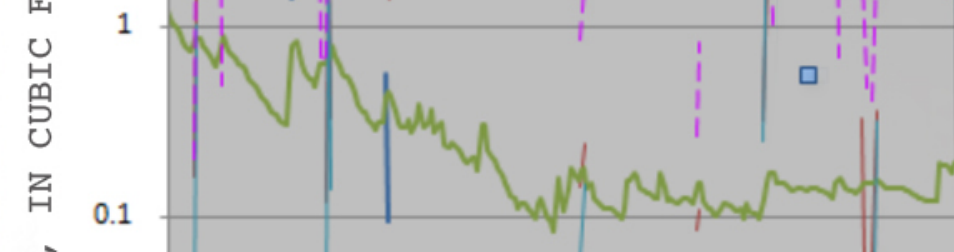

I

됭

年

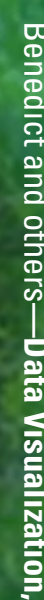

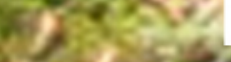

).

20

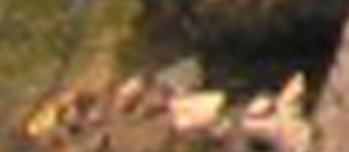

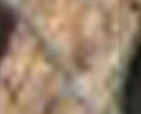

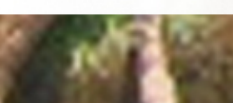

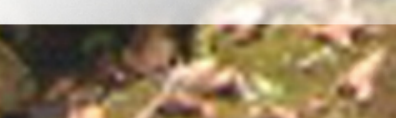

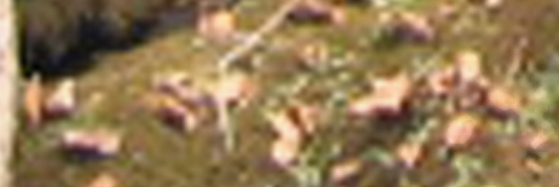

